\title{
A One Hundred -Year Study of the Upper Limit of Tree Growth (Terminus Arboreus) in the Swedish Scandes- Updated and Illustrated Change in an Historical Perspective
}

\author{
Leif Kullman $^{1 *}$, Lisa Öberg ${ }^{2}$ \\ ${ }^{I}$ Department of Ecology and Environmental Science,Umeå University,SE 90187 Umeå, Sweden \\ ${ }^{2}$ Department of Applied Science and Design, Mid Sweden University,SE 85170 Sundsvall, Sweden \\ "Corresponding Author:Leif Kullman, Department of Ecology and Environmental Science, Umeå \\ University, SE 90187 Umeå, Sweden
}

\begin{abstract}
Positional treeline change since the early 20th century and up to 2017 was assessed along three elevational transects on Mt. Getryggen in the southern Swedish Scandes. Baseline data, representing the year 1915, were compared with later intermittent records up to 2017. Concerned species were Betula pubescens ssp. czerepanowii, Picea abies,Pinus sylvestris and Alnus incana. These speciesresponded with different degrees of continuous upshift and substantial inter-site variability.Betula displayed the largest advance, by $215 \mathrm{~m}$. This maximum magnitude of change compares with data from widely different parts of the Swedish Scandes.This common performance indicates that regionally recorded summer warming by 1.5 ${ }^{\circ} \mathrm{C}$ is the ultimate cause. In a long-term historical perspective, most congenial conditions for birch and pine growth at high elevations prevailed around 10500 - $9400 \mathrm{cal}$. YrBP, when the local treelines reached 1355 and $1250 \mathrm{~m}$ a.s.l., respectively. The former elevation coincides with the upper limit of Vaccinium myrtillus and the low-alpine belt. With the exception for Pinus, recent treeline upshifts were accomplished predominantly by phenotypic responses of millennial-old krummholz specimens. Only occasionally, has treeline advance by Betula and Picea originated from seed regeneration during the past century. These circumstances may set the limit for further advance where and when the pool of high-altitude oldestablished krummholz specimens becomes depleted as existing krummholz individuals have already transformed to tree mode.
\end{abstract}

Keywords: Climate Change, Treeline Dynamics, Regeneration Modes, Betula pubescens ssp. czerepanowii, Picea abies, Pinus sylvestris, Alnus incana, Swedish Scandes

\section{INTRODUCTION}

Impacts and consequences of climate change and variability on the living landscape and its various compartments have become a common scientific and landscape management concern in recent days. Climate models disseminate a prospective view of ubiquitous and calamitous climate warming over the rest of the present century (IPCC 2013). Subalpine and alpine ecosystems, prevailing at their edge of climatic tolerance, are supposed to display first and straightforward responses to altered climatic conditions. Accordingly, alpine treelines and treeline ecotones, primarily considered to depend on altitudinally decreasing summer air and soil temperatures, emerge as primary monitoring targets and "early warning lines" in this context (Tranquillini 1979; Grace et al. 2002; Körner \& Paulsen 2004; Kullman 2007a, b, 2015a, b; Holtmeier 2003; Müller et al. 2016). They have by tradition been held to display clearly interpretable indications of changed growth conditions and pending landscape transformations in response to altered climatic conditions (Kullman 1998a, 2012, 2015b, 2017a; Fagre et al. 2003; Holtmeier 2003; Lloyd 2005; Nagy 2006; Harsch \& Bader 2011). However, a close association with altered climatic conditions has been disputed by certain authors (e.g. Olofsson et al. 2009; Van Bogaert et al. 2011), an option questioned by Kullman (2015b). Thus, further inquiry into this issue seems motivated.

Treeline studies in different parts of the world display large inter-site variations with respect to degree of upslope treeline shifts during the past 100 years of climate warming (Aas 1969; Kullman 1979, 2017a, 2018a, b; Hiller et al. 2001; Kapralov et al. 2006; Danby \& Hik 2007; Kullman \& Öberg 2009; Harsch et al. 2011; Mamet \& Kershaw 2012; Gaire et al 2014). In many cases, this circumstance relates to topoclimatic and ecological constraints in combination with ground cover and herbivory 
(Kullman 1979, 2007b; Shiyatov 2003; Dalen \& Hofgaard 2005; Selsing 2010; Elliott 2011; Leonelli et al. 2011, 2016; Holtmeier \& Broll 2011; Nagy et al. 2013; Aakala et al 2014; Schickhoff et al. 2015).A general problem within treeline science is that many recent studies suffer from unprecise treeline definitions (cf. Hustich 1979; Kullman 2010; Schickhoff et al. 2015), which impairs adequate inter-site and temporal comparisons. Moreover, recent treeline shifts may locally result from abandoned land use, contemporaneous with climate change, which further complicates cause attribution of past and modelling of future performance.

It may be a truism that the past has an influence on the present and future landscape structure (Burt 1994). Therefore, recent treeline dynamics can be properly understood only with a longer retrospective and observational view on the concerned ecosystem and its dynamics. In the Scandes, modern treeline change has to be evaluated in perspective of a virtually consistent retraction towards lower elevations throughout most of the Holocene, with an elevational nadir right before the onset of the modern episode of climate warming in the early 20th century (Kullman 2013, 2015b,c).

Effects of climate warming over the past century, subsequent to the dire, dark and cool centuries of the Little Ice Age (Lamb 2005; Grove 1988), offer a unique opportunity to improve our understanding of the relationship between landscape-scale high-elevation tree growth and thermal conditions. Despite predictions of pending climate warming and extensive forest encroachment on the alpine tundra (Kellomäki et al. 1997; Moen et al. 2004; ACIA 2005; Kaplan \& New 2006), there is little factual evidence of ongoing change in that direction, at the general landscape scale (Kullman 2016b). This discrepancy between models and the real world performance may be a consequence of lacking understanding of climate-treeline relationships, giving rise to over-simplified models, not subjected to proper validation tests. These aspects constitute the background and rationale of the present study, which mainly focuses on factual elevational dynamics of precisely defined treelines during the past 100 years of the dominating tree species in the southern Swedish Scandes. Concerned species are mountain birch (Betula pubescens ssp. czerepanovii), Norway spruce (Picea abies) Scots pine (Pinus sylvestris) and Grey alder (Alnus incana). A particular focus is on change during the past 10-15 years, as a measure of endurance of treeline shifts. Moreover, different modes of treeline shifts are highlighted. The results are viewed in perspective of local and regional Holocene treeline history.

\section{STUdy AREA}

\subsection{Location, Climate, Physiogeography and Land Use}

The present study focuses on treeline performance on Mt. Getryggen in the southern Swedish Scandes, $63^{\circ} 11^{\prime} \mathrm{N} ; 12^{\circ} 19^{\prime} \mathrm{E}$ (Fig. 1). The mountain peak is at $1382 \mathrm{~m}$ a.s.l., while surrounding valley bottoms linger about 700-750 $\mathrm{m}$ a.s.l.The bedrock consists of amphibolite and gneisses and is covered with glacial till, fluvi-glacial deposits and peat. Predominant soils in the treeline ecotone are shallow Spodosols. The study site is ideal for monitoring treeline movements. An even topography and adequate soils provide possibilities for upslope tree advancement over the mountain slopes. Particularly important is the fact that this mountain has been in the focus of different generations of treeline researchers since the early 20th century. Thus, modern treeline dynamics may be evaluated against a proper baseline record, a truly unique circumstance.

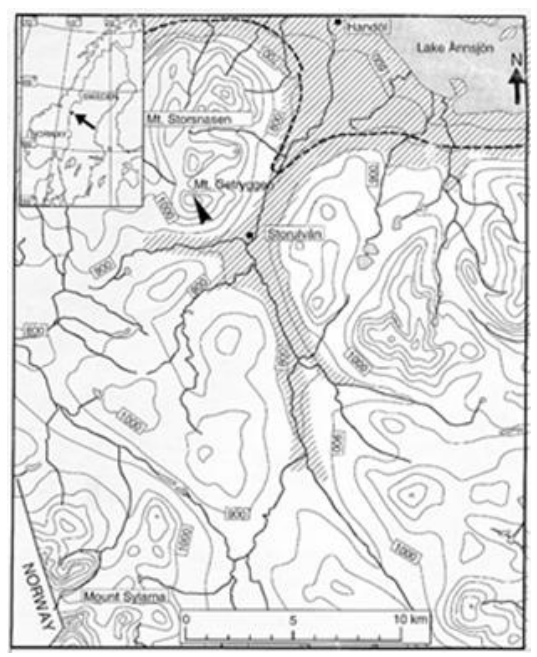

Fig. 1 Location map, showing the position of Mt. Getryggen (arrow) in the Handölan Valley, northern Sweden. 
With respect to the climate character, the concerned mountain is within a transition zone between suboceanic and sub-continental influences (Raab \& Vedin 1995). The nearest official meteorological station (Storlien/Visjövalen, $642 \mathrm{~m}$ a.s.1., $20 \mathrm{~km}$ to the northwest) accounts for climate data, representing the so-called normal period 1961-90. Mean temperatures for January, July and the year are -7.6, 10.7 and $1.1{ }^{\circ} \mathrm{C}$. For the same period of time, annual precipitation averages $857 \mathrm{~mm}$, of which $45 \%$ is snow (Swedish Meteorological and Hydrological Institute).

\subsection{Modern Climate Change (Instrumental and Proxy Records)}

Like the situation in many other northern regions worldwide, the climate in this part of the Scandes has improved during the past 100 years, as expressed by records from Storlien/Visjövalen meteorological station (see above), with data from the early 20th century. For the period June August and December-February, significant linear trends, of +1.5 and $1.4{ }^{\circ} \mathrm{C}$, respectively, were recorded. Summer warming was most prominent during the first four decades of the 20th century, with a broad peak in the late 1930s (Figs. 2,3). Thereafter, the temperatures have prevailed at a relatively high level, although with a large variability on the scale of years and short periods of years. Winter temperature has shown a more consistent warming trend since the early 20th century. However, the swings between single years have been larger than displayed by the summer temperature. Precipitation has increased by c. $15 \%$ since the early 20th century (Alexandersson 2006; Kullman 2007a, b).

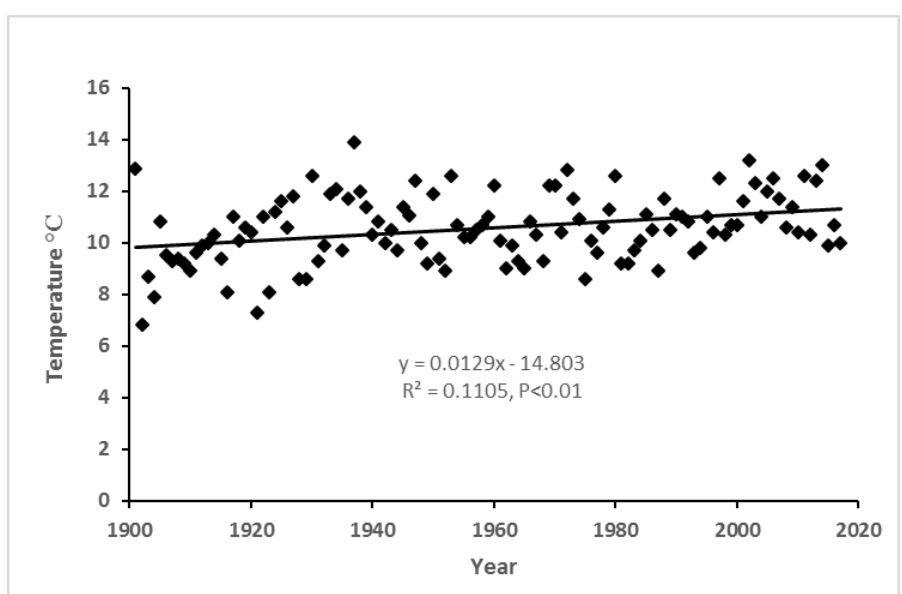

Fig. 2 Annual records (1901-2017) of June-August temperature at Storlien/Visjövalen meteorological station

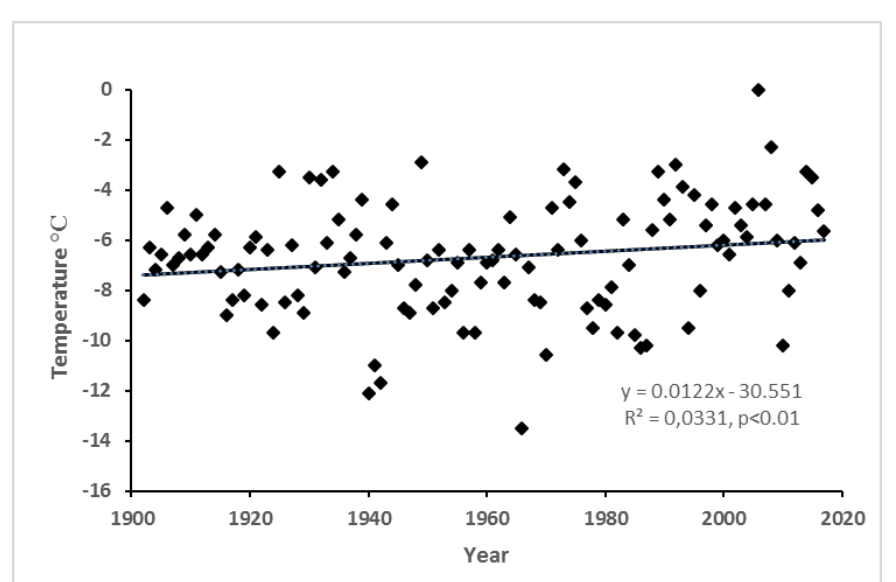

Fig. 3 Annual records (1901-2017) of December-February temperature at Storlien/Visjövalen meteorological station

Proxy records of centennial climate change are provided by shrinking glaciers, earlier melt-out of alpine/subalpine snow patches and vanishing or reduced permafrost. In addition,snowmelt and birch leafing in the subalpine forest belt nowadays takes place about two weeks earlier than in the early 20th century (Kullman 2016a). As a consequence of earlier and more complete snow-melt, the ground in alpine and subalpine areas in general is found to have dried out at earlier dates annually during the past century, with cascading ecological effects (Smith 1957; Wistrand 1962; Kullman 2004). 


\subsection{Plant Cover}

The study area provides a representative view of the subalpine biogeographic organization of the Swedish Scandes. A discrete subalpine belt with almost monospecific predominance of mountain birch (Betula pubescens ssp. czerepanovii) currently prevails between c. 700 and $900 \mathrm{~m}$ a.s.1. On the mountain here concerned, the upper distribution of closed birch forest stops at a broad front along a topographic discontinuity in the form of "knee", 840 m.a.s.l., representing transition from concavity to a flat terrace (Fig. 4). Solitary tree birches, minor groves and a few narrow wedges extend substantially higher, benefitting from local wind shelter. Large and late-thawing snow patches at high elevations provide more or less continuous supply of meltwater throughout the summer, which supports the well-developed birch forest belt below, also embracing extensive mires.

Scattered specimens of subordinate tree species prevail in the birch forest - Sorbus aucuparia, Picea abies, Pinus sylvestris, Populus tremula and Alnus incana. Except for Sorbus, which as a tree extends virtually as high as Betula, all other tree species have their respective treelines in the lower reaches of the birch belt.

The treeline is the limit for successful survival of the tree form. Henceforth, the treeline is narrowly defined for each species as the maximum elevation (m a.s.1.) of individuals with stems at least $2 \mathrm{~m}$ tall (cf. Miehe \& Miehe 2000; Hofgaard et al. 2013; Kullman 2016a). Elevational treeline dynamics integrates climate-vegetation interactions on scales of decades to centuries and longer. Compared to other delimitations of the forest to alpine tundra transition, this treeline definition provides the most clear-cut ecological expression of prevailing climate conditions, particularly apt for adequate comparisons in space and time (Fagre et al. 2003; Nagy 2006; Kullman 2010).

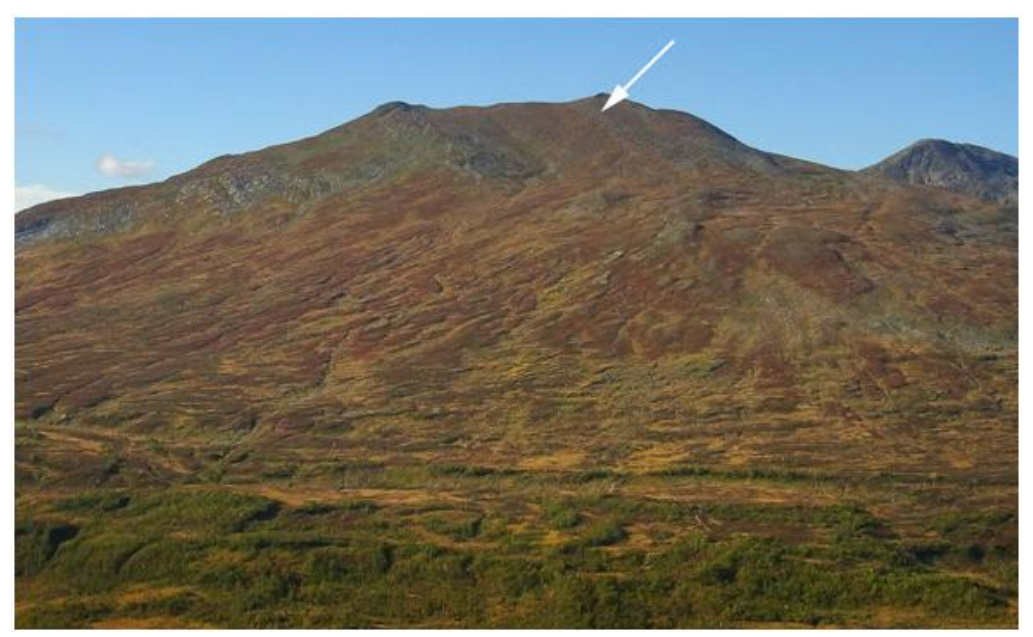

Fig. 4 The south-facing slope of Mt. Getryggen. Continuous birch forest stops beneath the distinct terrace around $840 \mathrm{~m}$ a.s.l., while small groves and solitary trees extend to much higher elevations. The arrow indicates the position of a recovered megafossil birch, i.e. the birch treeline of the early Holocene (cf. Fig. 6). Photo: $2010-09-10$.

The ground cover vegetation in the birch forest and up to the top of the mountain is affected by summer grazing and trampling by reindeer (Rangifer tarandus), which since the early Holocene constitute an integral part of this environment. An expression of this situation is that in the Sami tradition, the study mountain is named "Reindeer Mountain" (Sw. Renfjället). Past human usage is indicated by the finding of an iron arrow head, which recently melted out from a late-lying snow patch, and probably it was lost in connection with reindeer hunt about 1000 years ago (Öberg \& Kullman 2011). A Sami dwelling site prevailed until the early 20th century close to the valley floor on the southeast facing flank of the mountain. Associated activities caused some local thinning of the birch forest, although leaving the treeline ecotone virtually unaffected.

Since the early 20th century, reindeer numbers have increased steadily in this region (Kullman 2016a), which has to be taken into account in connection with evaluation of recent vegetation dynamics in these mountains. Aside of Sami utilization, human disturbance to the plant cover is considered to be neglible (Virtanen et al. 2003), although this mountain is currently frequently used by tourists, both summer and winter. 


\subsection{Holocene Arboreal History}

The course of present-day vegetation and treeline evolution integrates modern climate change and variabilty with vegetation structures and patterns reflecting climate and environmental change during earlier epochs of the Holocene. Therefore, a short historical overviewmay be motivated, as a basis for interpretation of the obtained results in perspective.

For long, vegetation history has been synonymous with pollen analysis. However, that approach has been proven to provide an imperfect and incomplete view of Holocene treeline elevation, composition and structure (Kullman 2002, 2008, 2017b; Elven et al. 2013). A more qualitatively accurate view in these respects is provided by analyses of megafossil tree remains, preserved in peats and under glacial ice (Kullman 2013, 2017b). It appears that all of our principal treeline trees were present in northern and western Scandinavia at early deglaciated nunataks already during the Late-Glacial, high above (500-700m) current treeline positions. The relatively highest elevations of tree growth were obtained 11 500-9000 cal. yr BP, forced byhigher than present orbitally driven summer solar irradiance and accordingly summer temperatures, about $3{ }^{\circ} \mathrm{C}$, warmer than during the past few decades (Kullman 2017a,b). Exampels of high-elevation tre growth during this period are provided by megafossils of Pinus and Betula (Figs. 5, 6). Remnants of a small birch tree were exposed by minor soil erosion close to the wind-swept peak of the mountain, $1355 \mathrm{~m}$ a.s.l. (Fig. 6). This is $310 \mathrm{~m}$ higher than the birch treeline of the present day (Kullman \& Öberg 2009). The site coincides with the upper limit of Vaccinium myrtillus and features of podzolization in the soil. Tentatively, this implies that, in general, the upper limit of Vaccinium myrtillus may be used as proxy for the maximum elevation of tree growth during the warmer-than-present early Holocene.

As evident from robust megafossil records, environmental conditions during the early Holocene also enabled the growth of warm-demanding broad-leafed trees (9500-7000 cal. yr BP), such as Quercus robur, Corylus avellana, Ulmus glabra, Alnus glutinosa and Tilia cordata, at relatively high subalpine elevations (the study area included), currently dominated by cool-adapted boreal species, foremost mountain birch, spruce and pine (Kullman1998b,c, 2008). Megafossil analyses provide substantially earlier records of presence of the thermophiles than interpreted by local and regional pollen analyses (Hafsten 1992; Giesecke 2005). This discrepancy highlights a more general methodological problem in vegetation history (Kullman 2017b).

Apparently, the early Holocene high-elevation forests contained a richer tree flora than today. In particular Alnus incana constituted a prominent member of the the early suabalpine ecosystems. Picea abies, for long erroneously considered as a late-Holocene immigrant to the Scandes (e.g. Huntley \& Birks 1983), prevailed at high elevtions during the early Holocene, also on Mt. Getryggen (Fig. 7). Subsequently, gradual cooling was initiated and maintained throughout much of the Holocene, which forced regression of the dominating pine treeline ecotone and the warmth-demanding trees. As a further consequence of this Neoglacial environmental change, the present-day character of the treeline ecotone gradually evolved. The result was the current zonation pattern, characterized with a distinct upper subalpine birch forest belt and montane spruce/pine forests below. Apparently, the subalpine birch forest belt was initiated in the wake of a distinct cooling episode around 8200 cal. yr BP (Kullman 2013). This course of climate and associated regressive tree cover evolution reached a Holocene nadir by the late 19th century, culminating with the Little Ice Age of the past 700 years or so (Grove 1988).

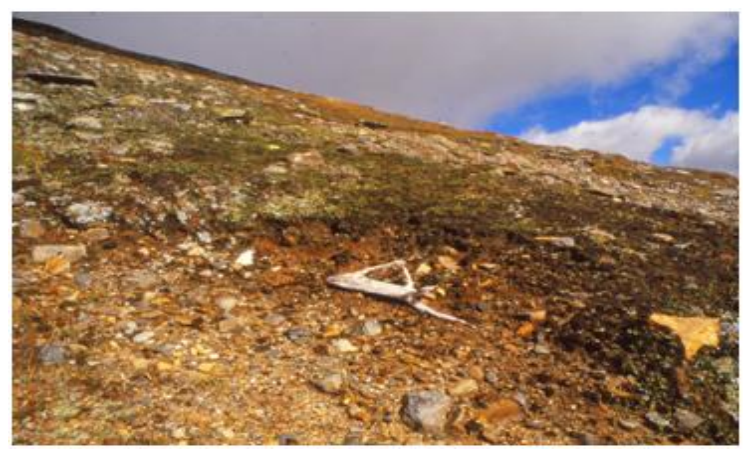

Fig. 5 Megafossil remains of a pine tree, recently exposed by wind erosion. The position is $1250 \mathrm{~m}$ a.s.l., which is $515 \mathrm{~m}$ higher than the present-day treeline in this slope. Radiocarbon dating yielded 10520 cal. yr BP. Photo: 2003-09-01. Source: Kullman \& Kjällgren (2006). 
Substantial warming of the past 100 years represents a fundamental break in the Holocene course of climate and biogeographic evolution (Kullman 2003; Kullman \& Kjällgren 2006; Kullman \& Öberg 2009). Recent treeline rise of Betula and Pinus have locally reached levels higher than any time during the past 5000-7000 years (Kullman 2013, 2017a). In fact, temperature reconstructions from the southern Swedish Scandes indicate a long-term cooling trend over the past 1000 years prior the recent warm phase (Kullman 2015c; Fuentes et al. 2017).

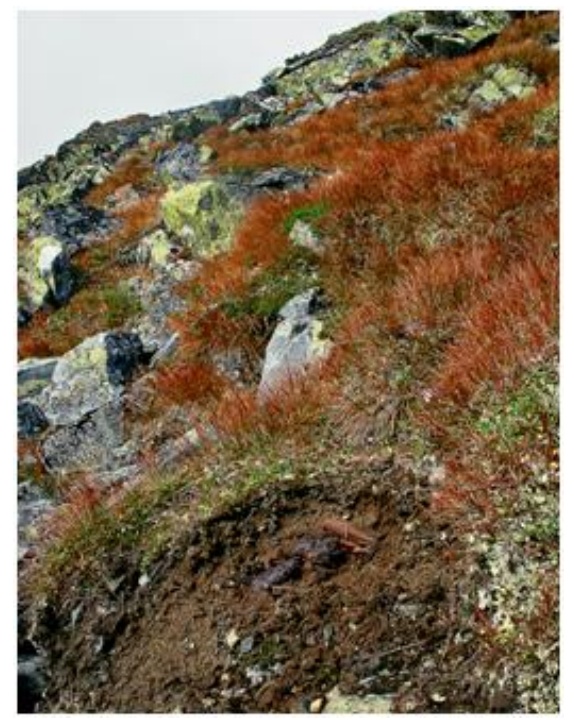

Fig. 6 Erosion scar (1355 $m$ a.s. l.) close to the peak of Mt. Getryggen, which has exposed wood remnants of birch, dated $9370 \mathrm{cal}$. yr BP. The site is indicated by an arrow in Figure 4. Photo: 2012-09-12.

Notably, present-day climate and biotic change, as focused in this paper, take start from a natural bottom level, representing "ice age-near" climatic conditions and climaticallydepauperized ecosystems (cf. Auger \& Payette 2010). It is important to consider, however, that treeline rise over the past 100 years has not been an overall monotonic course of change. A severe, although transient, climatic set back during the late 1980s caused extensive tree and sapling mortality at treelines in the study region (Kullman 1989).This experience is fundamental to the current discourse concerning anticipated future climate change and landscape evolution.

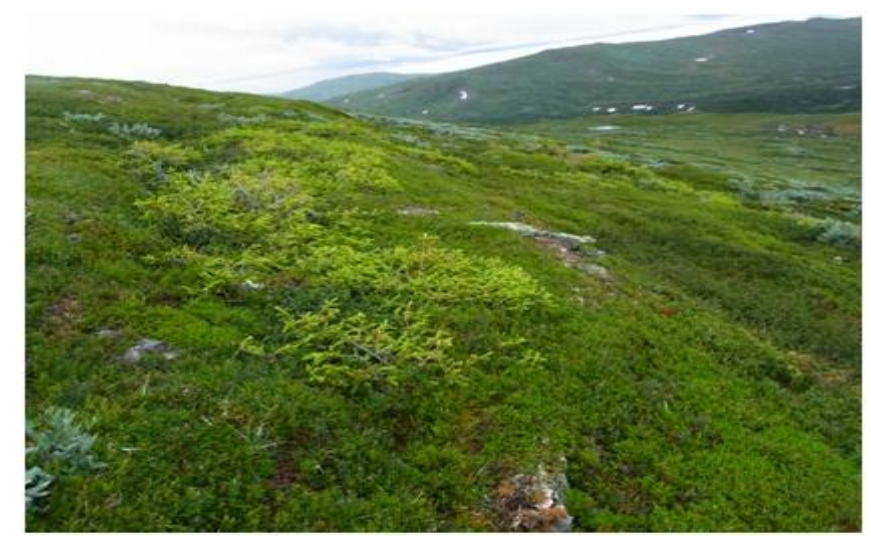

Fig. 7 An extensive spruce krummholz individual on the south-west facing flank of the mountain, $995 \mathrm{~m}$ a.s.l. Megafossil wood remains were dug out in the center of the formation and dated 6860 cal. yr BP (Beta-474250). Photo: 2012-07-31.

\section{METHODS}

\subsection{Positional Treeline Shift}

Treeline shift was elucidated along broad elevational belt transects, centred upslope of the treeline positions given by Smith (1920) and resurveyed by Kullman (1979) and Kullman \& Öberg (2009). A recent treeline survey of three of the mountain slopes was carried out in 2017, i.e. east, south and southwest-facing aspects, SITE 1-3, respectively. Each site embraces about $1 \mathrm{~km}$ in width. Trees beyond the treeline position by the mid- 1970s were positioned (GPS) and tallied. Some specimens 
had been photographed at earlier occasions, which enabled rephoto analysis and clear-cut evidence of the overall character of change or stability.

The accuracy of Smith's tree-line records, with virtually the same definition as the one used here, was assessed and confirmed by boring birches at $2 \mathrm{~m}$ above ground level (Kullman 1979). Tree rings were counted in the laboratory, using a stereomicroscope.

\subsection{Experimental Studies}

Based on regional studies of centennial treeline change of mountain birch and spruce, it appeared that positional treeline progression has to a high degree relied on phenotypic plasticity rather than processes related to the regenerative niche (Kullman 1979, 1986a, 2010,). In order to shed some further light on this aspect, long-term experimental studies were initiated on Mt. Getryggen in the late 1970s and early 1980s. Early life history stages of birch were specifically studied, e.g. seed quality, seed bank, germination in the field, establishment, and early-life survival. Details and results of these studies (until 1992) are given by Kullman (1984, 1986, 1993). The latest survey was carried out during the autumn 2013 and is reported below.

Annual records of birch germinability were tested on seed collected in a stand $775 \mathrm{~m}$ a.s.l. on the south-facing slope of Mt. Getryggen. Percentage viable seeds was tested in the laboratory (cf. Kullman 1984). The possibility of a birch seed bank was elucidated by the burial of see lot of 5000 seeds in the lower part of the A-horizon, $5 \mathrm{~cm}$ below the soil surface. Viability was tested intermittently until 2013.

A sowing experiment was initiated in the autumn of 1980. Seeds of local provenance with $15 \%$ germinability were sown on mineral soil in three contrasting habitats where the ground cover had been removed; - Birch forest, $775 \mathrm{~m}$ a.s.l., Snow Bed, $825 \mathrm{~m}$ a.s.l. and Tree-limit, $930 \mathrm{~m}$ a.s.l. The number of living seedlings was surveyed annually 1980-2013.

A transplantation experiment was initiated in 1978. For that purpose, naturally established seedlings of virtually uniform size and age, c. $4.5 \mathrm{~cm}$ tall and $3 \mathrm{yr}$ old were planted in three contrasting habitats 820-830 $\mathrm{m}$ a.s.l., where the original vegetation had been removed. These habitats were Windswept crest, Moderate snow bed and Extreme Snow bed.

Further nuances to the interpretation of results obtained by the observed treeline dynamics of dominant native species were gained from the outcome of a small-scale trial with planted native Pinus sylvestris and some exotic tree species in the mid part of the birch belt in a sparse and snow-poor Empetrum-lichen heath, situated on the east-facing slope of Mt. Getryggen, $800 \mathrm{~m}$ a.s.l. (Kullman 1985). Planting was carried out in the early summer of 1980, and comprised $0.5-0.8 \mathrm{~m}$ tall saplings of the following species, Picea abies, Picea omorika, Picea pungens, Picea engelmannii and Larix sibirica. All plants were produced in the nursery of Arboretum Norr in Umeå and were provided by Dr. C.G. Thögersen. Survival, height growth and injuries have been monitored annually up to 2017 .

\section{Results}

\subsection{SITE1. East-facing slope of Mt. Getryggen}

\subsubsection{Birch Treeline}

Smith (1920) measured the treeline of mountain birch to be at $810 \mathrm{~m}$ a.s.l., a value which was confirmed as reasonable by boring an old-looking tree $2 \mathrm{~m}$ above the ground level at this specific elevation (Fig. 8) (Kullman 1979). By the mid-1970s, the treeline had reached 920 m a.s.l. (Fig. 9) (Kullman 1979) and in 2007 it was positioned at $940 \mathrm{~m}$ a.s.l. (Kullman \& Öberg 2009). The most recent assessment was in 2017, when $945 \mathrm{~m}$ a.s.l. was attained by the advancing treeline (Fig. 10). Thus, over the past 100 years, the treeline has shifted $135 \mathrm{~m}$ upslope. This continual course of change is paralleled with increased ramification and foliation of birches growing in the treeline advance zone (Fig. 11).

Treeline rise relative to the position prevailing in 1915, seems to have been accomplished predominantly by phenotypic plasticity of old-established polycormic specimens, i.e. transformation from prostrate to erect tree form. Judging from the presence/absence of stools with multiple stems, recently established specimens are rare in the zone where the treeline advanced during the past hundred years (Fig. 10). 
A One Hundred -Year Study of the Upper Limit of Tree Growth (Terminus Arboreus) in the Swedish Scandes- Updated and Illustrated Change in an Historical Perspective

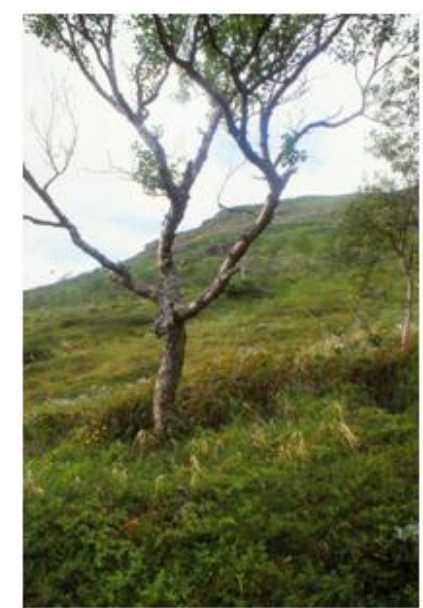

Fig. 8 This birch, growing at $810 \mathrm{~m}$ a.s.l. represents the treeline around 1915, as evident from dendroecological analysis and field records (Smith 1920). Photo: 2003-07-20.
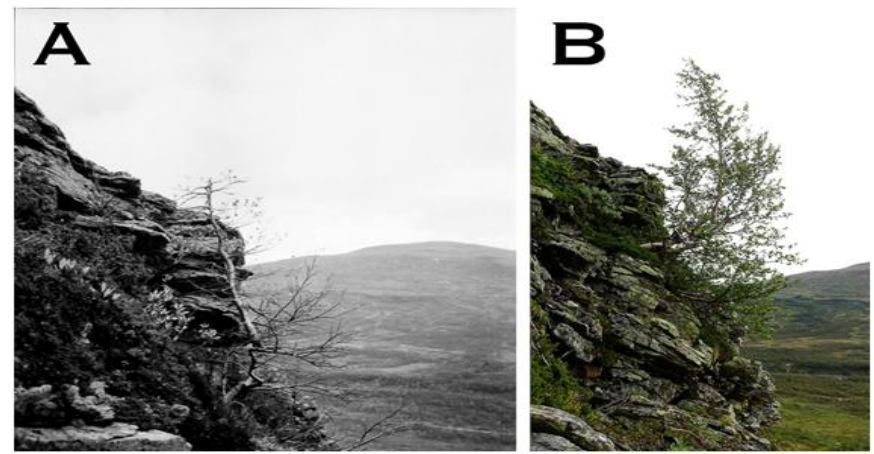

Fig. 9 A.In the mid-1970s, a solitary birch tree, $920 \mathrm{~m}$ a.s.l., with a recently broken top marked the treeline Photo: 1978-08-15. B. The same tree has recovered substantially up to the present day. Photo: 2017-08-15.
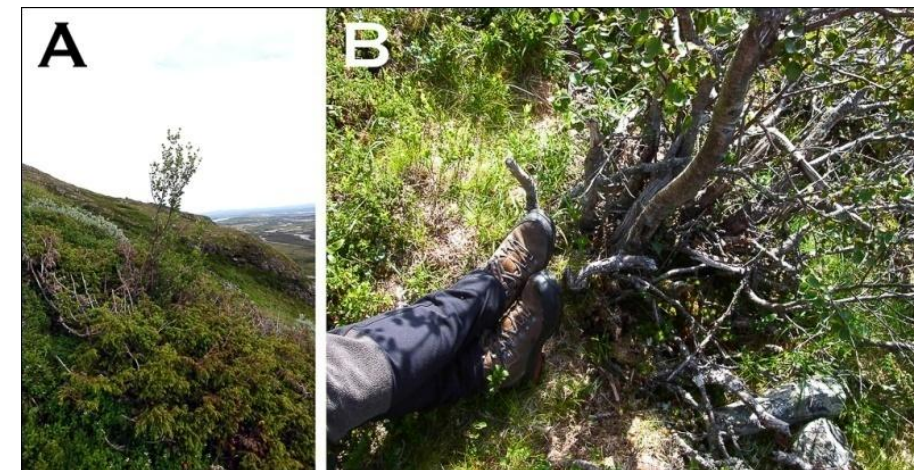

Fig. 10 A. The new and higher treeline, $945 \mathrm{~m}$ a.s.l., attained after 2007. Photo: 2017-08-15. B. An extensive and multi-stemmed stool of stems from the same root indicate that this is a decidedly old-established specimen. Photo: 2017-08-15.
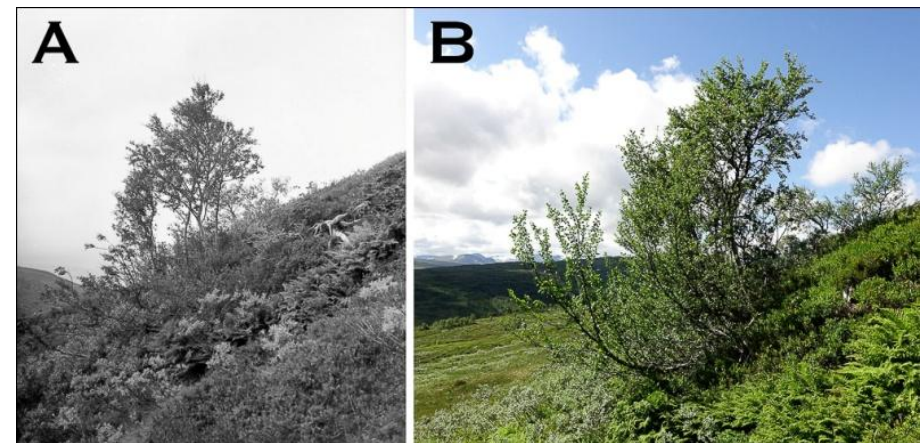

Fig. 11 A.Polycormic birch copse growing $890 \mathrm{~m}$ a.s.l., i.e. $80 \mathrm{~m}$ atop of the position held by the early 20th century. The largest steminitiated rapid height growth in the early-1940s. Photo: 1973-06-28. B. During the past 3-4 decades, this specimen has been affected by heavy snow pressure and over the same time foliation has increased. Photo: 2017-08-03. 

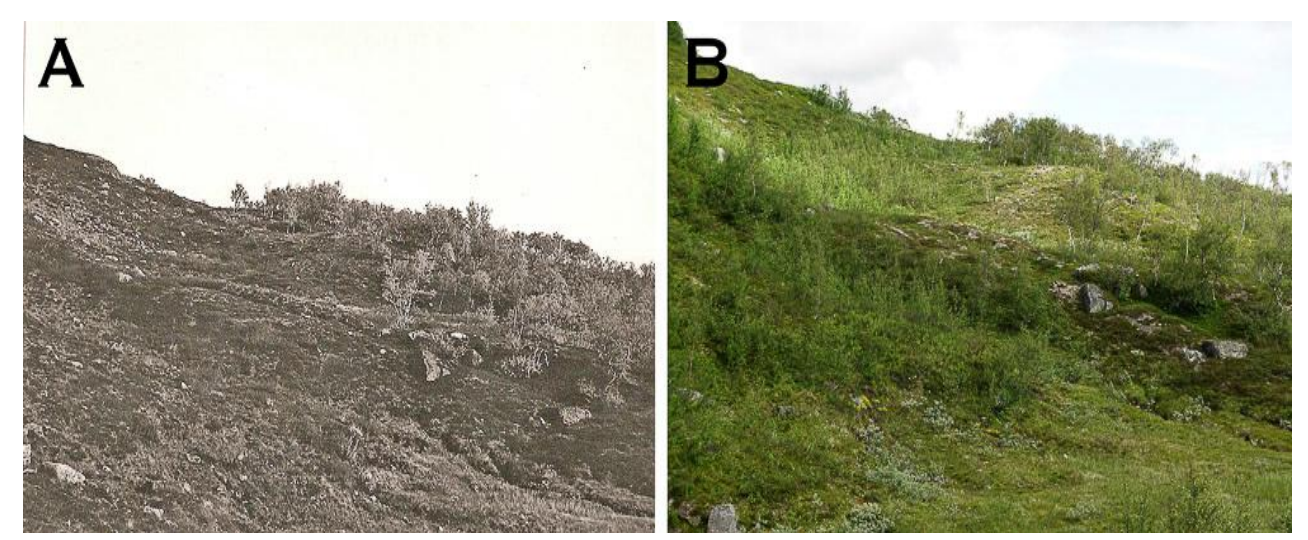

Fig. 12 A. In the early 1980s, this topographic depression, $795 \mathrm{~m}$ a.s.l., in the birch forest was totally devoid of trees, although prostrate specimens lingered in the ground cover. Large masses of late-lying snow restricted their growth to trees. Photo: 1980-09-07. B. Up to the present day, the snow cover has tended to melt increasingly early, and as a consequence, birch vegetation has proliferated, with trees more than $4 \mathrm{~m}$ tall. Photo: 2017-08-07.

Below the treeline, substantial ingrowth of birch has taken place in topographic concavities, where previously too much late-lying snow precluded tree growth. This phenomenon is highlighted for a site on the lower east-facing slope of Mt. Getryggen (Figs. 12,13). An age structure study revealed that by the early 20th century, a sparse cover of low-growing birches prevailed at the bottom of the depression. A peak of instatement of new stems occurred in the 1930s. Intermittent observations show that until the late 1980s, these birches staggered as low growing shrubs $(<0.5 \mathrm{~m}$ tall). Subsequently and up to the present day, stem density and height have increased substantially, without perceivable stem mortality. By 2017 the height of the stand was $4.3 \pm 1.02 \mathrm{~m}$, to be compared with $0.12 \pm 0.03 \mathrm{~m}$ in 1980. A more detailed account of the evolution of birch growth at this site is given by Kullman (2016c).

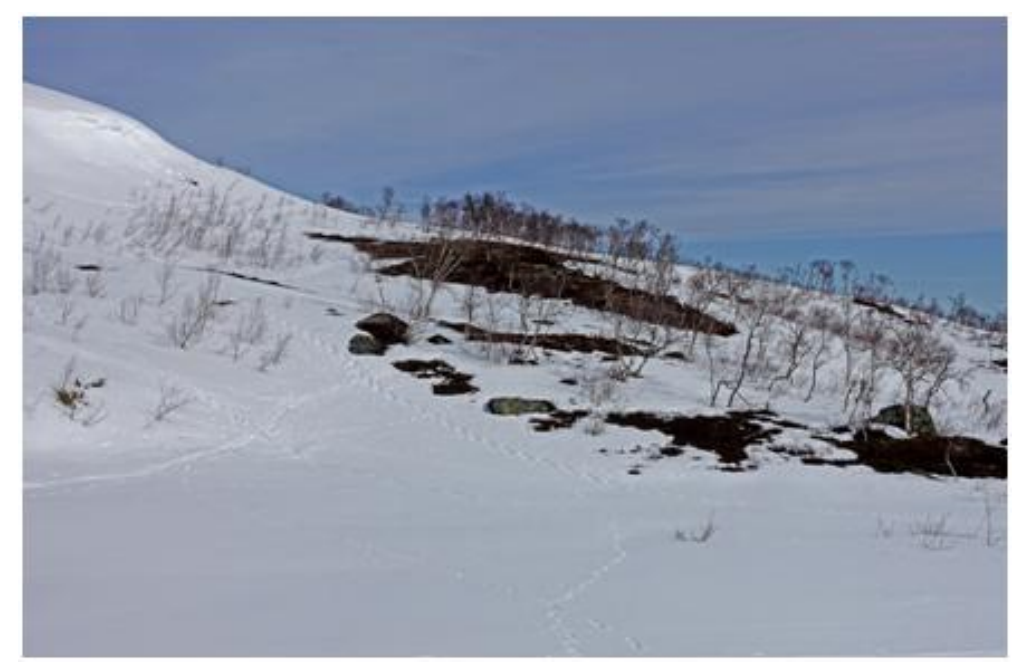

Fig. 13 The same view as depicted in Fig. 12, showing its character as a snow-accumulating site. The new birch population has benefitted from snow retraction at the lower margin of the huge snow drift.The birch stand at the opposite and relatively snow-poor side of the depression is virtually unchanged or has somewhat declined in density over the same period of time. Photo: 2016-05-02

\subsubsection{Spruce Treeline}

Spruce occurs infrequently as clonal groups in the birch forest belt on this slope. Radiocarbon dates of subfossil wood preserved underneath the clones indicate that presence of spruce is an ancient feature here, with its roots in the mid- Holocene or earlier (Figs. 14, 15) (Kullman 2001). Dendroecological analysis indicated that by the early 20th century the treeline was positioned $730 \mathrm{~m}$ a.s.l. in the form of a multi-millennial old specimen (Fig. 14) (Kullman 1996). Present-day treeline is at $830 \mathrm{~m}$ a.s.l. Thus, during the past 100 years, the treeline has advanced by $100 \mathrm{~m}$, as a consequence of increased height increment of ancient krummholz indviduals, existing prior to the 20th century (Fig. 16). Seed regeneration has been extremely sparse during this period of time. 
A One Hundred -Year Study of the Upper Limit of Tree Growth (Terminus Arboreus) in the Swedish Scandes- Updated and Illustrated Change in an Historical Perspective

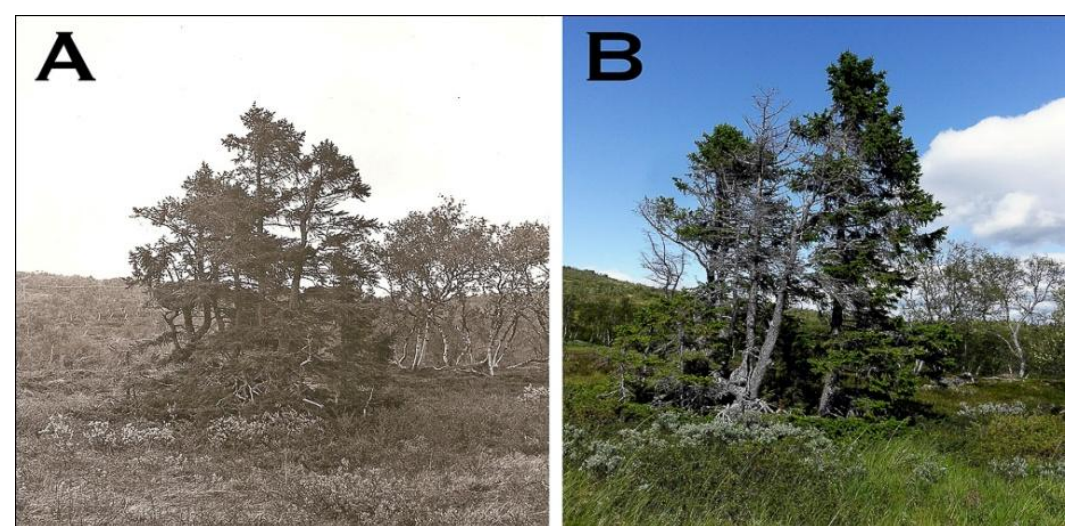

Fig. 14 A. The spruce treeline, $730 \mathrm{~m}$ a.s.l. as it was in the early 20th century and until the mid-1970s. This specimen is radiocarbon-dated 5905 cal. yr BP (Kullman 2001). The oldest living stems are more than 400 years old. Photo: 1973-06-28. B. During the past few decades, the vitality has perceivably declined and some of the major stems have died. No seedlings or saplings have appeared in the neighbourhood. Photo: 2017-08-14.

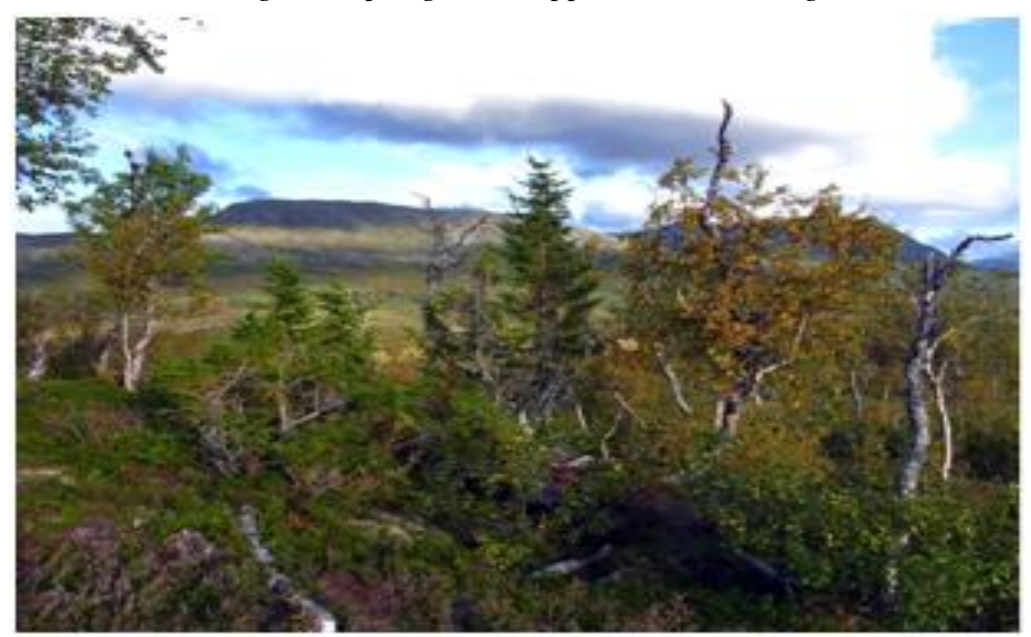

Fig. 15 This specimen, $770 \mathrm{~m}$ a.s.l. further attests to the long-term stability of spruce distribution on this slope. Wood remnants buried in the soil indicate that this spruce existed 5650 cal. yr BP. Tree size was attained well after 1915 and thus this spruce was part of the treeline rise process during the past 100 years. The spruce is legally protected as a nature memory ( $S w$. naturminne) and is named Old Pompe, to the memory of a legendary dog.Photo: 2011-08-31.

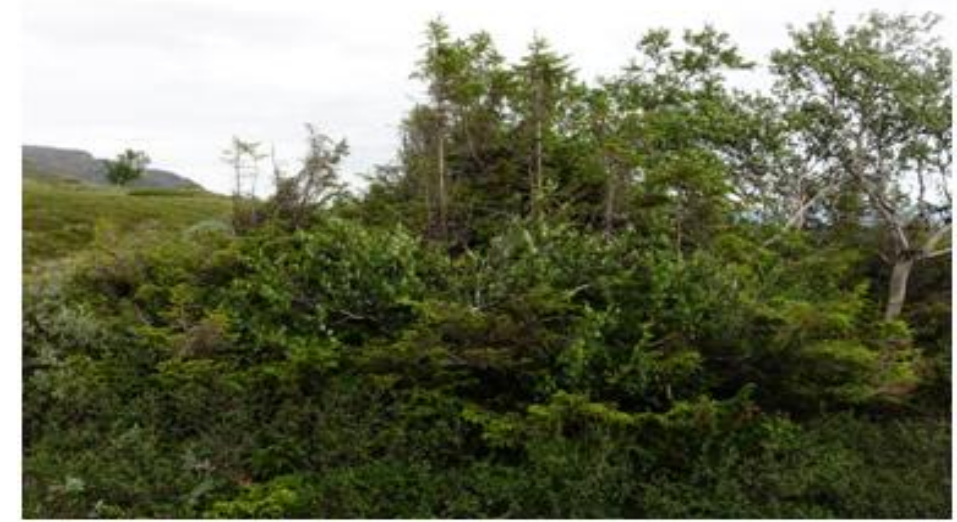

Fig. 16 The new and raised treeline of spruce is manifested by this specimen, $830 \mathrm{~m}$ a.s.l. Stout basal trunks show that the spruce existed at this spot as a low-growing shrub by the early 20th century. Tree size was attained in the mid-1970s, when the highest stems measured $2.2 \mathrm{~m}$. At the present day, this is still the treeline and the stems have reached a height of $3.5 \mathrm{~m}$. Photo:2017-08-15

\subsubsection{Pine Treeline}

During the past 100 years, the treeline of pine has risen from 700 to $775 \mathrm{~m}$ a.s.1., i.e. $75 \mathrm{~m}$ in elevation, as manifested by tree-sized pines, younger than 80 years, growing above the early-20th 
century treeline (Fig. 17, 18). In one case an upshifted pine of this category produced offspring during the early 21 st century (Fig. 19). Seed regeneration and elevational pine expansion is largely confined to open habitats, such as mire margins and sparse birch forest. Hereabouts, young pines have continually increased in size and vigor up to the present day.

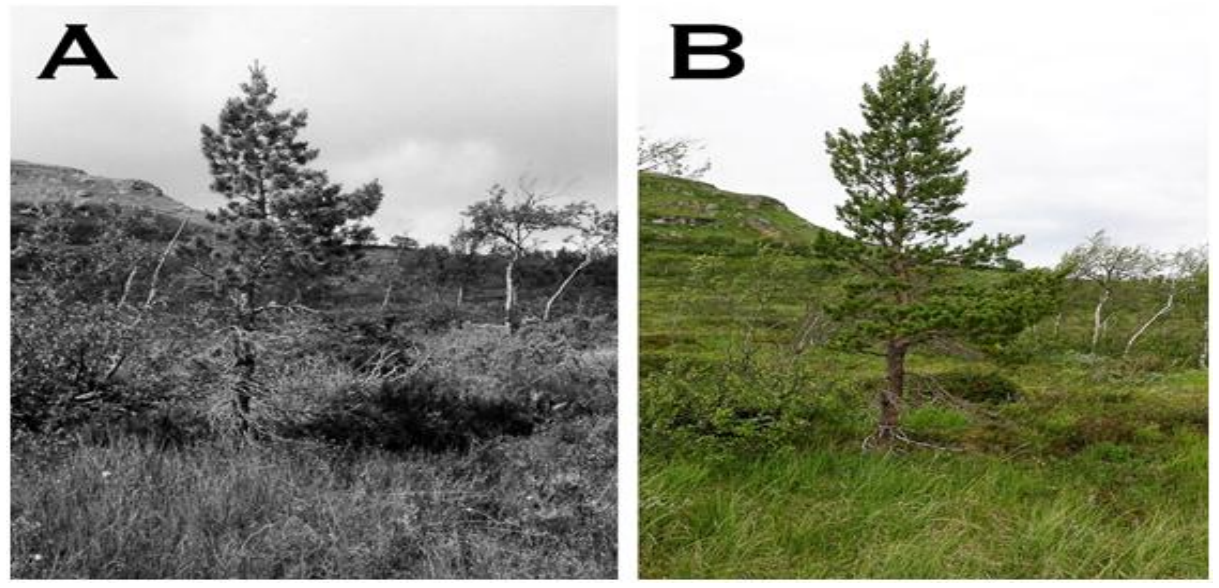

Fig. 17 The present-day treeline, $775 \mathrm{~m}$ ö.h., characteristically established in an open habitat, such as a mire margin. The tree became established in the mid-1950s. A. Photo:2004-07-26, B. Photo: 2017-08-15.

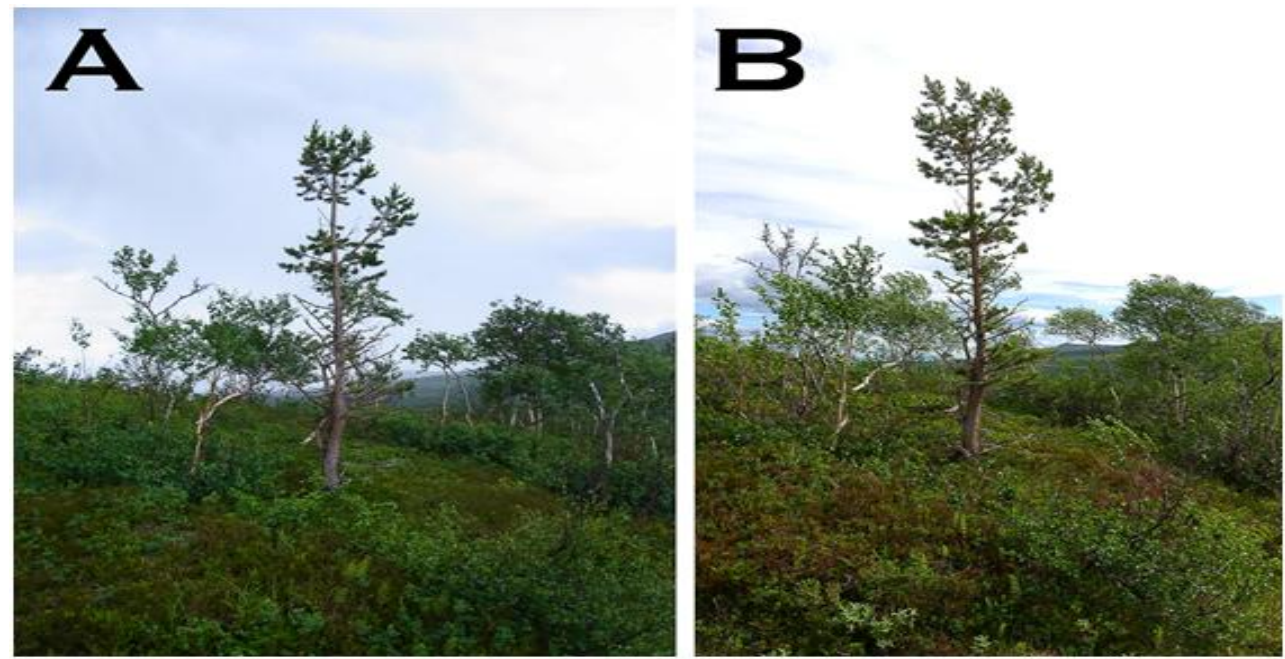

Fig. 18 Pine, $770 \mathrm{~m}$ a.s.l., which is part of the elevational expansion process and penetration into open spaces at increasingly higher elevations in the birch forest belt. A. 2012-07-31. B. 2016-06-30.
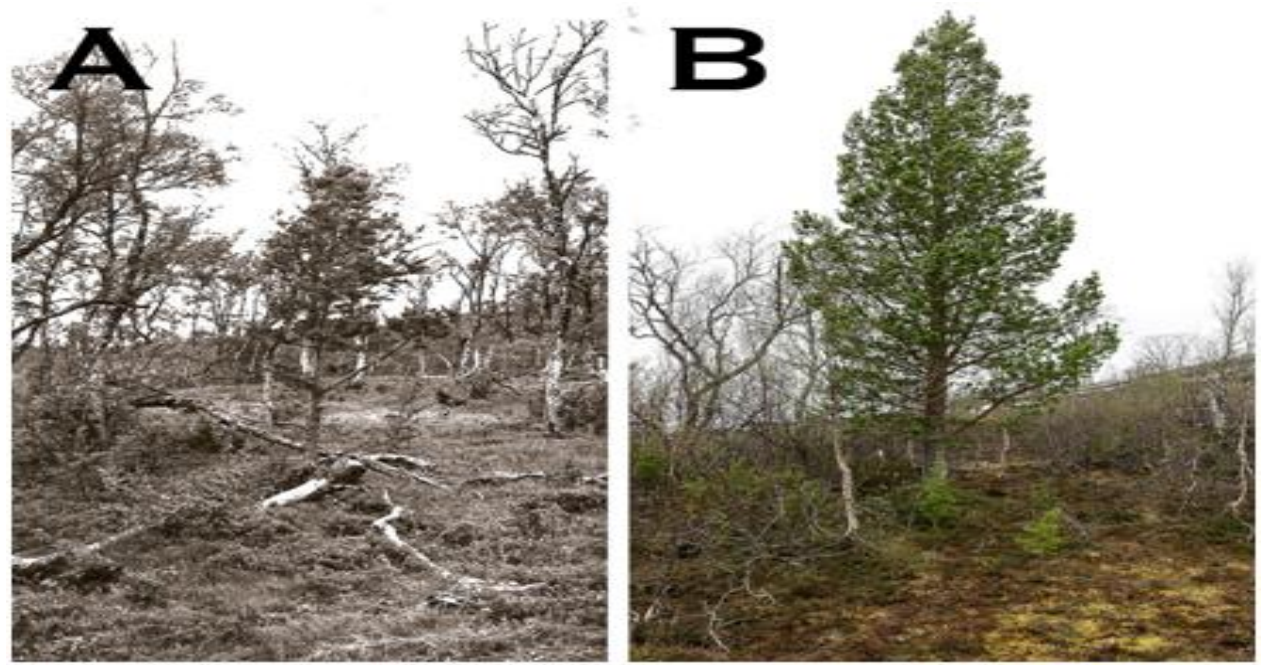

Fig. 19 A. Solitary pine, $750 \mathrm{~m}$ a.s.l., established in the early-1940s and growing $50 \mathrm{~m}$ above the treeline of the early-20 century. Around 1990, this pine was $3.4 \mathrm{~m}$ high. Photo:1991-07-12. B. Until the present day, this pine has gained vitality and a size of $5.5 \mathrm{~m}$. Photo: 2017-06-10.During the past 10 years or so, the pine has produced offspring within a radius of $c .10 \mathrm{~m}$. 
A One Hundred -Year Study of the Upper Limit of Tree Growth (Terminus Arboreus) in the Swedish Scandes- Updated and Illustrated Change in an Historical Perspective

\subsection{Site 2. South-Facing Slope of Mt. Getryggen}

\subsubsection{Birch treeline}

Smith (1920) measured the treeline of mountain birch to be at $830 \mathrm{~m}$ a.s.l., a value which was confirmed by Kullman (1979), by means of boring an old-looking and still living tree, $2 \mathrm{~m}$ above ground level (Fig. 20). No such old trees were confirmed at higher elevations. This aspect was further tested in 2017, when 21 trees, at approximately the same elevation, were bored by the same premises. It turned out that 15 of 21 trees were older than 100 years at the boring stem position, which means that they were $2 \mathrm{~m}$ or higher in 1915. Older trees were looked for at higher elevations, but no one was found. These results further strengthen Smith's estimate.

In 1951, Kilander (1955) recorded the treeline at $906 \mathrm{~m}$ a.s.l. Buried wood remains, associated with an extant tree stem (Fig. 21) at virtuallythe same elevation, are dated $4770 \mathrm{cal}$. yr BP (Öberg \& Kullman 2012).Moreover, (Smith 1920) noticed prostrate birches 920 m a.s.l. and Kilander (1955) found a $1.5 \mathrm{~m}$ high thicket $920 \mathrm{~m}$ a.s.l. and $1 \mathrm{~m}$ shrubs at $950 \mathrm{~m}$ a.s.l. Thus paleoecological and subrecent data suggest that a pool of prostrate birches existed high above the treeline prevailing by the early 20th century. Birches within this category may be the result of phenotypic regression of prior tree-sized birches, in response to Neoglacial cooling of the past 3000 years or so and survival in that state up to the present day (Kullman 2013). Taken together, these circumstances support the contention that modern treeline rise is mainly accomplished by phenotypic progression of birches contained in a pool of old-established relict krummholz birches growing above the treeline of the early 20 th century.
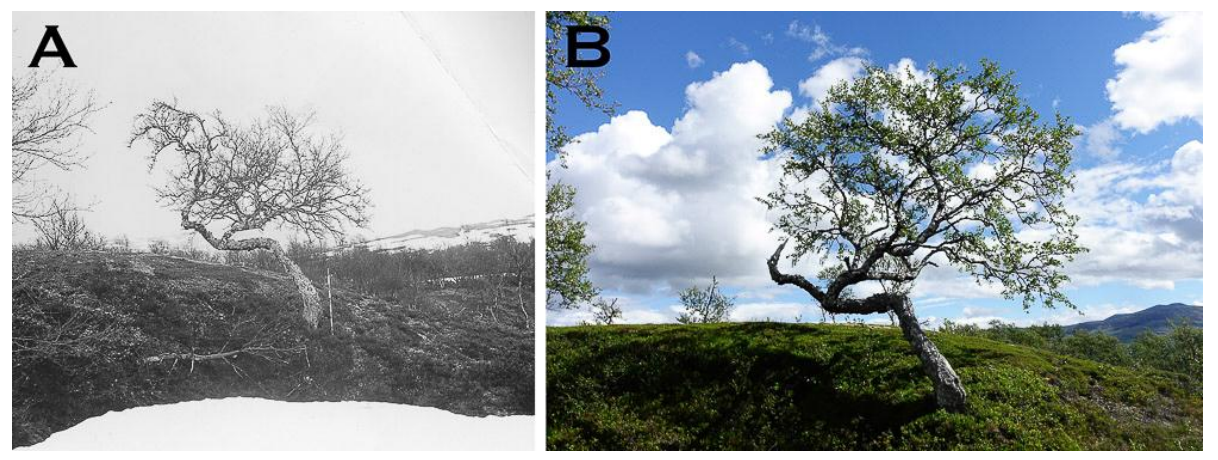

Fig. 20 A. Old-growth birch, $830 \mathrm{~m}$ a.s.l., representing the treeline position around 1915. Photo: 1974-06 -07. B. The same tree as it appears today. On major branch has been lost. Photo: 2017-08-08.
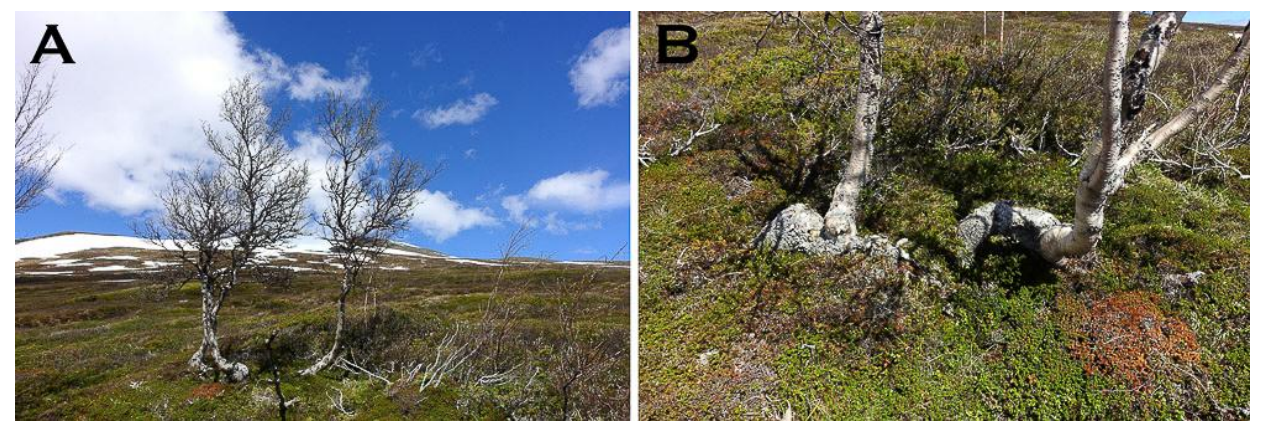

Fig. 21 A. Birch tree, $905 \mathrm{~m}$ a.s.l., which marks the treeline position by the early 1950s. This specimen like many others alike existed in a more low-growing form much earlier.B. Radiocarbon-dated wood remnants in theupper soil and associated with living stems yielded a date of 4770 cal. yr BP (Source: Öberg \& Kullman 2012).

By the mid-1970s, the treeline had reached $930 \mathrm{~m}$ a.s.l. (Kullman 1979) (Fig. 22) and in 2007 it was still positioned at the same elevation (Kullman \& Öberg 2009). The most recent assessment was in 2017, when $1045 \mathrm{~m}$ a.s.l. was reached by the advancing treeline in the form of a slender and youngish looking specimen (Fig. 23). The evolution of this specimen has been followed over a period of 37 years, from tiny sapling, severely browsed by hare or reindeer, to current tree form (Figs. 23, 24).

Over the past 100 years, the treeline has shifted $215 \mathrm{~m}$ upslope. The most recent phase of this continual course of this change is depicted in a series of photos (Figs. 23-27). 
A One Hundred -Year Study of the Upper Limit of Tree Growth (Terminus Arboreus) in the Swedish Scandes- Updated and Illustrated Change in an Historical Perspective

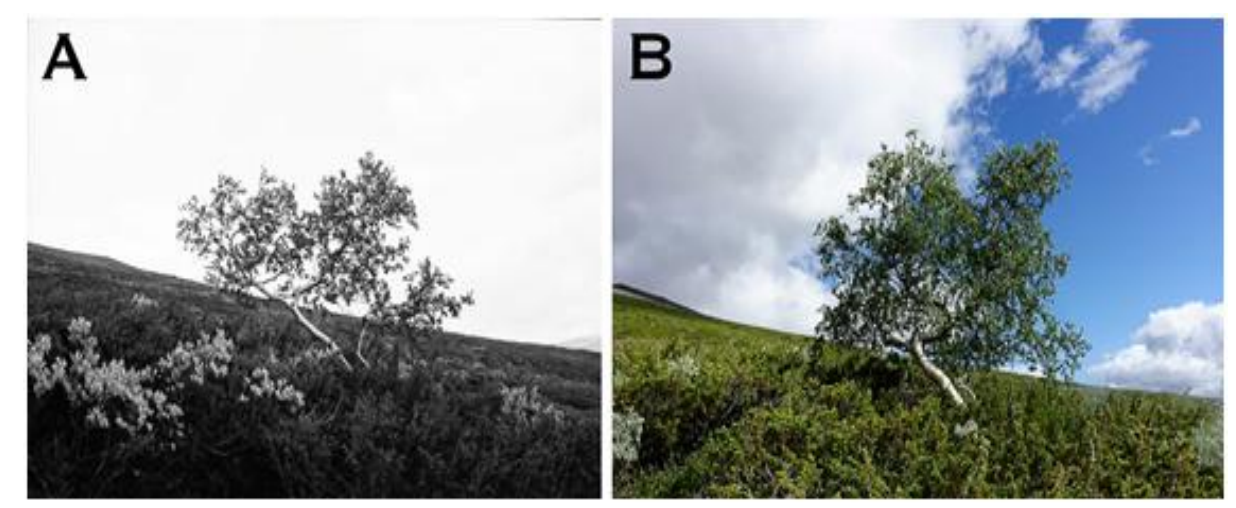

Fig. 22 A. By the mid-1970s, the treeline had advanced $100 \mathrm{~m}$ in elevation, to $930 \mathrm{~m}$ a.s.l., as represented by this tree. Photo: 1979-08-08. B. An up-to-date version of the same tree displays crown expansion and increased foliation. Photo: 2017-08-08.

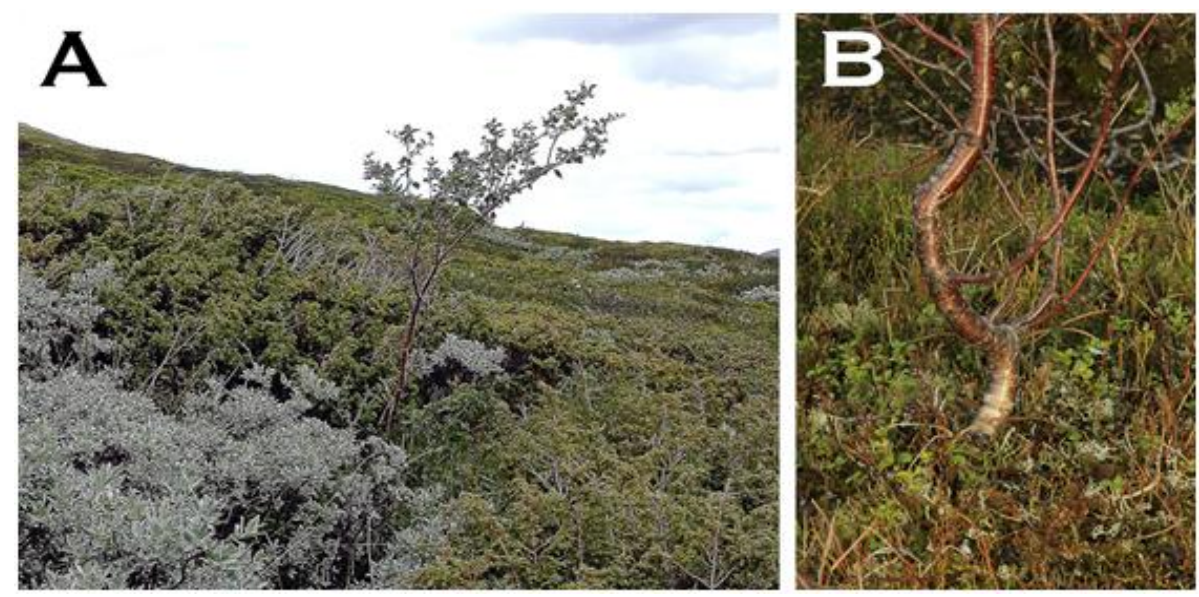

Fig. 23 A. The new and most recent treeline position is manifested by this small tree, $1045 \mathrm{~m}$ a.s.l. The evolution of this specimen has been followed from its early seedling stage in 1980 (Fig. 24) to the present tree-size mode.Photo: 2017-08-03. B. Basal part of the birch depicted in A. Single-stemmed specimens of this kind are generally interpreted as seed-generated during some recent decades.Photo: 2016-09-29.
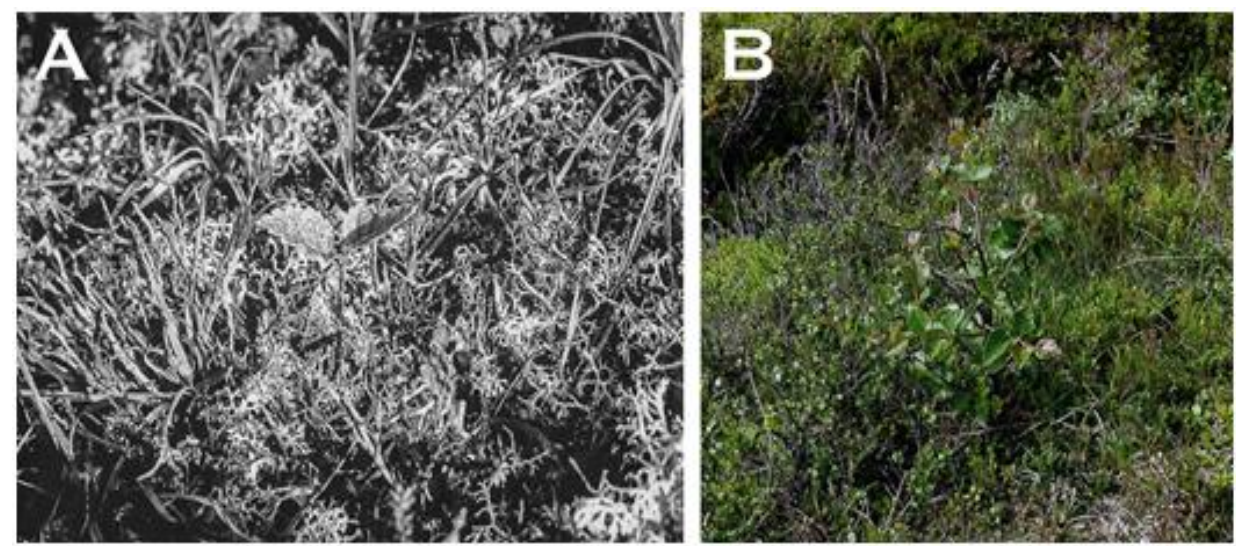

Fig. 24 Early stages in the evolution of the treeline birch depicted in Fig. 23. A. A $5 \mathrm{~cm}$ high sapling in undisturbed vegetation of lichens and sedges. Photo: 1980-07-28. B. Heavy browsing by reindeer or hare has checked the height growth (40 cm high) and promoted evolution of multiple shoots. Photo: 1988-07-18.

As depicted above, treeline rise relative to the position prevailing by the mid-1970s, has been accomplished to some extent by quite newly established individuals. This contrasts with treeline rise during earlier periods of the 20th century, when plastic phenotypic responses of old-established multistemmed specimens seem to have been the rule (Öberg \& Kullman 2012).

Conspicuously, many trees in the treeline advance zone have increased their foliation over the past few decades. These specimens have frequently suffered from winter browsing by hare (Lepus timidus). Despite heavy damage to twigs and buds, birches often survive this brutal treatment, which may decide growth form at the mature stage (Fig. 25). 

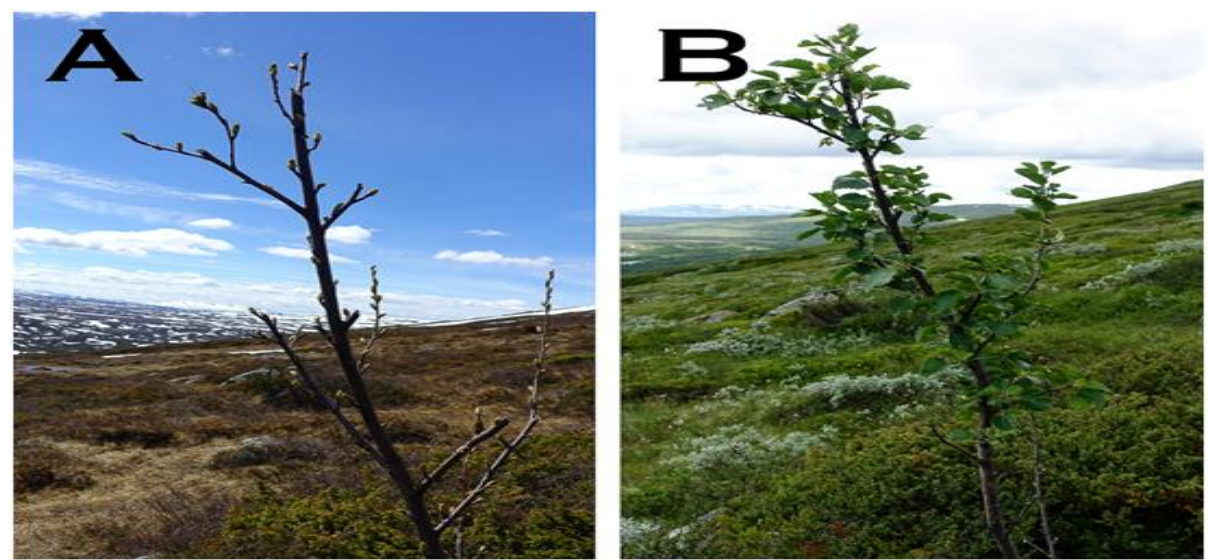

Fig. 25 Young birch tree in the upper treeline advance zone, $965 \mathrm{~m}$ a.s.l. A. In the early summer, it displayed signs of heavy browsing by hare. B. As evident later in the same summer, it survived this treatment with a more compact crown and foliation, which may impact its future growth form. Photo: 2017-08-03.
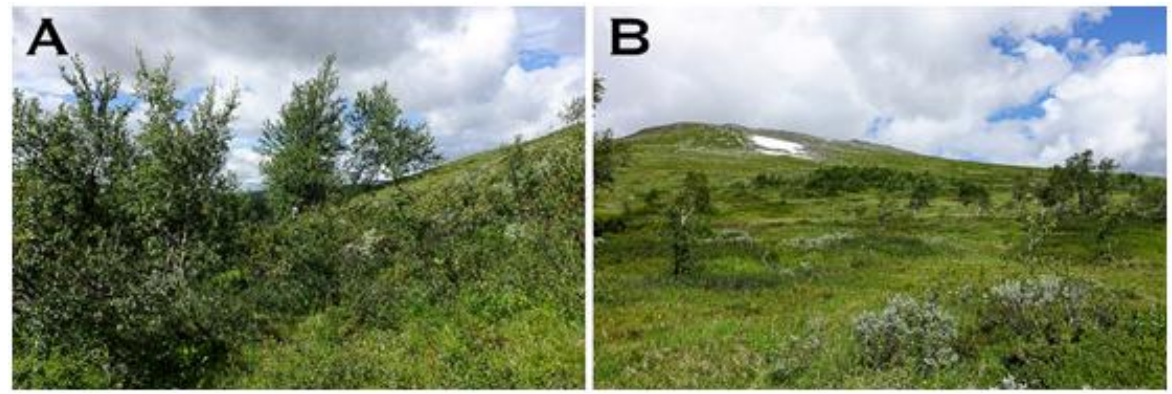

Fig. 26 A. A wedge of closed forest protruding upslope to $905 \mathrm{~m}$ a.s.l. Photo: 2017-08-09. B. The same forest from below, $835 \mathrm{~m}$ a.s.l., i.e. right at the treeline position by the early-20th century. Birch clustering here relates to a steady supply of meltwater from the snow patch higher upslope.Photo: 2017-08-08.

Strictly locally in this slope, the upper boundary of closed forest has advanced upslope to $900 \mathrm{~m}$ a.s.l. in the form of a narrow wedge, which is associated with the main melt water stream from late-lying snow patches in the alpine region (Fig. 26). The present forest limit position is to be compared with 830 (1949) and 840 m a.s.l. (1978), given by Kilander (1955) and Kullman (1979), respectively.

During the first decade of the 21 st century, young seedlings of birch, spruce and pine were observed at the rim of vanishing snow patches(Fig. 28), virtually up to the peak of the concerned mountain. At the present day, most of these seem to be extirpated (cf. Kullman 2014 and updates).

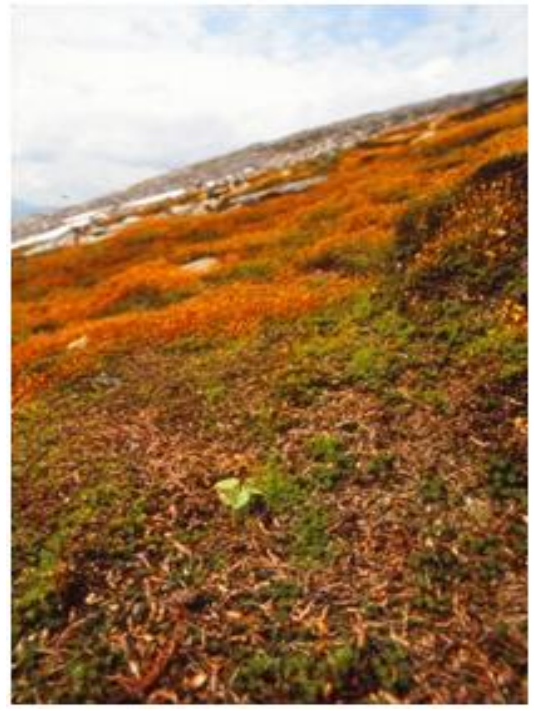

Fig. 28 Increasingly recent melt-out of snow patches has conditioned the evolution of moss mats (Polytrichastrum sexangulare) in the alpine region (here $1205 \mathrm{~m}$ a.s.l.), where in addition, scattered birch seedlings have become established in spots where the cover of mosses has been grazed by lemmings (Lemmus lemmus). Photo: 2003-07-13. 


\subsubsection{Spruce Treeline}

Spruce is currently a truly rare tree in this slope, dwindling in the dense birch forest. Some of today's uppermost trees existed as low-growing krummholz by the early 20th century. At that time, the treeline was at $770 \mathrm{~m}$ a.s.l. (Kullman 1986). Thereafter, it has advanced by means of accelerated height increment of old-established krummholz spruces to $820 \mathrm{~m}$ a.s.l. (Fig. 29). This implies treeline rise by $45 \mathrm{~m}$ over the past 100 years, although stability and consolidation since the mid-1970s. A few solitary seed-generated tree spruces have established between the treeline of the early 20th century and the present treeline. (Fig. 30).

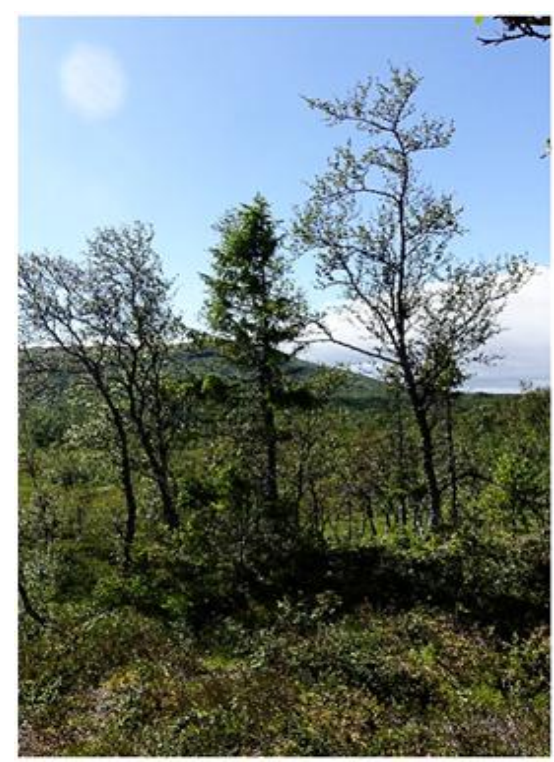

Fig. 29 Old-growth spruce, $820 \mathrm{~m}$ a.s.l., which developed from a low shrub in the early-20th century to an erect tree by the mid-1970s. During the past few decades, the foliation has increased and the treeline seems to be stabilized at this elevation.Photo: 2017-08-14.

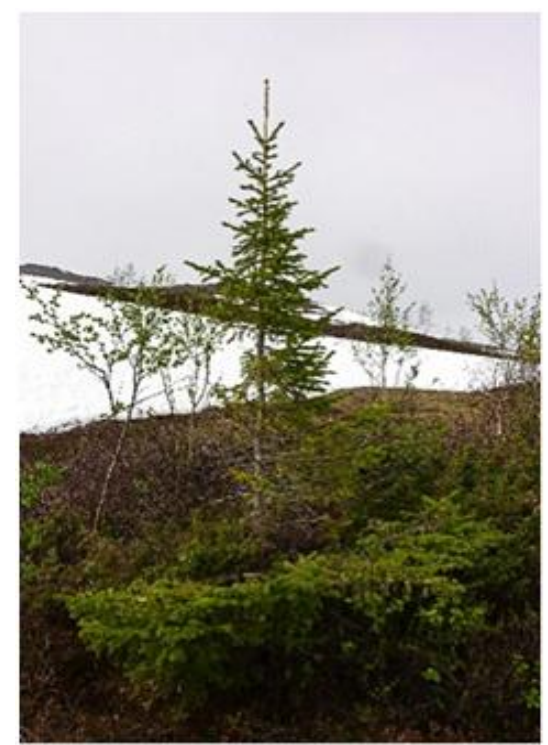

Fig. 30 Quite unusually today, young and fast-growing seed-generated spruce trees have emerged in sparse birch forest close to the treeline. $810 \mathrm{~m}$ a.s.l. Photo: 2017-06-17.

\subsubsection{Pine Treeline}

A solitary and fast-growing pine has established at a mire margin in the lower slope, $740 \mathrm{~m}$ a.s.l. (Fig. 31). Large subfossil wood remnants of tree-sized pine, at the same elevation, with $>200$ tree rings, indicate that thisspecimen, represents the minimum elevation of the early-20th century treeline (Fig. 32). Thus, virtually no treeline rise during the past 100 years is manifested here, although pine has locally reclaimed its Mediaeval position, from which it was depressed by Little Ice Age cooling (cf. Kullman 2015) or cutting by the Sami population, formerly dwelling here in the neighborhood. 
Establishment of pine in this slope is largely prohibited by densified birch forest stands around the pine treeline.A few widely scattered pine saplings have emerged in the lower reaches of the alpine tundra (Fig. 33).
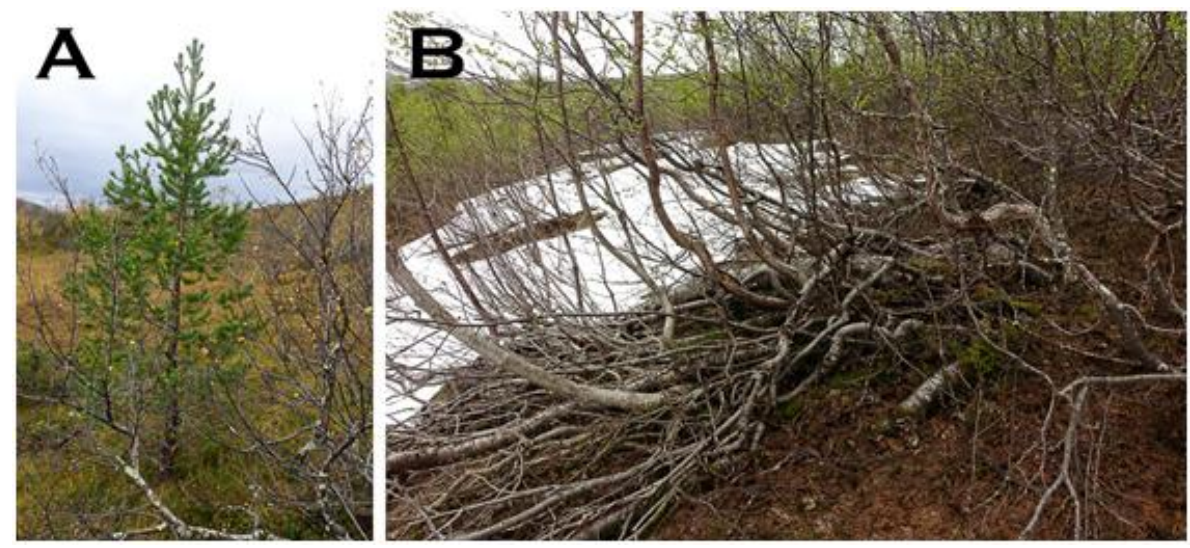

Fig. 31 A. Present-day pine treeline, $740 \mathrm{~m}$ a.s.l., in the form of a $3.5 \mathrm{~m}$ high idividual, established in the early1980s. The site is a mire margin. Photo: 2016-09-23. B. Dense birch forest around the pine treeline $1750 \mathrm{~m}$ a.s.l.), in combination with snow retention into the summer, counteracts pine establishment in this part of the slope. Photo: 2017-06-17.

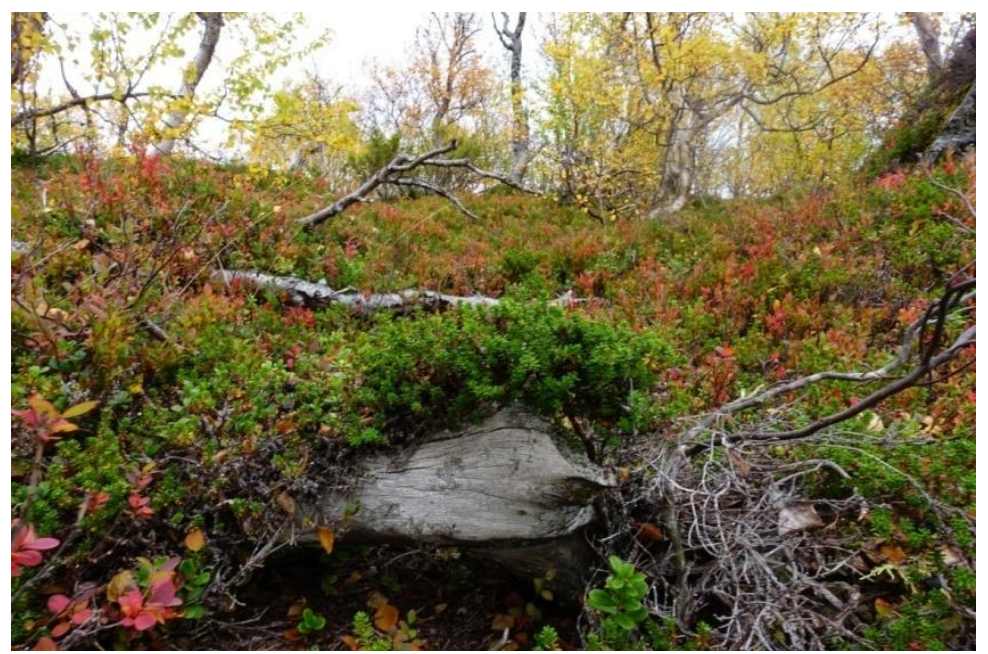

Fig. 32 Megafossil pine tree remnant, $740 \mathrm{~m}$ a.s.l. Radiocarbon-dating yielded 465 cal. yr BP (Beta446537).Photo: 2016-09-23.

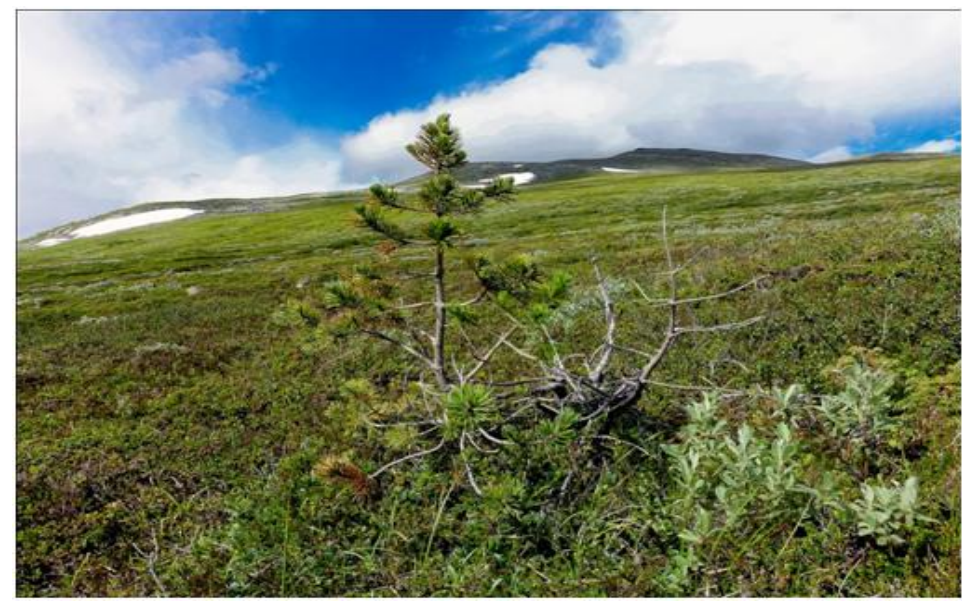

Fig. 33 Young pine sapling, $0.6 \mathrm{~m}$ tall, growing in alpine tundra $895 \mathrm{~m}$ a.s.l. Dead twigs indicate repeated winter desiccation, when passing the maximum depth of the snow cover.Photo: 2017-08-08.

\subsubsection{Grey Alder Treeline}

Today Grey alder (Alnus incana) is a rare tree in the subalpine birch belt (Kullman 1992), which contrasts with the situation prevailing in the first part of the Holocene (cf. Kullman 2013).In this 
specific slope, clonally perpetuating relict individuals occur in the subalpine birch belt, nearly as high in elevation as the uppermost birches (Kullman 1992). Radiocarbon-dated wood remnants indicate that one such multi-stemmed tree-sized and still living specimen existed already $4400 \mathrm{cal}$. yr BP (Kullman 2013). It remained as a low-growing shrub until the late 1990s. Thereafter, it has grown in height, to reach $3 \mathrm{~m}$ in 2017 (Fig. 34). Tree-sized alders displaying more than 100 year rings $2 \mathrm{~m}$ above ground-level exist $755 \mathrm{~m}$ a.s.l. and indicate tentatively by comparison with the present position that the treeline has advanced $135 \mathrm{~m}$ over the past 100 years.

By the early 21 st century, young seedlings and saplings were observed at the fringe of receding snow patches high above current treeline of both alder and birch (Fig. 35). Many of these have succumbed during recent years, of prolonged seasonal snow cover duration (cf. Kullman 2014).
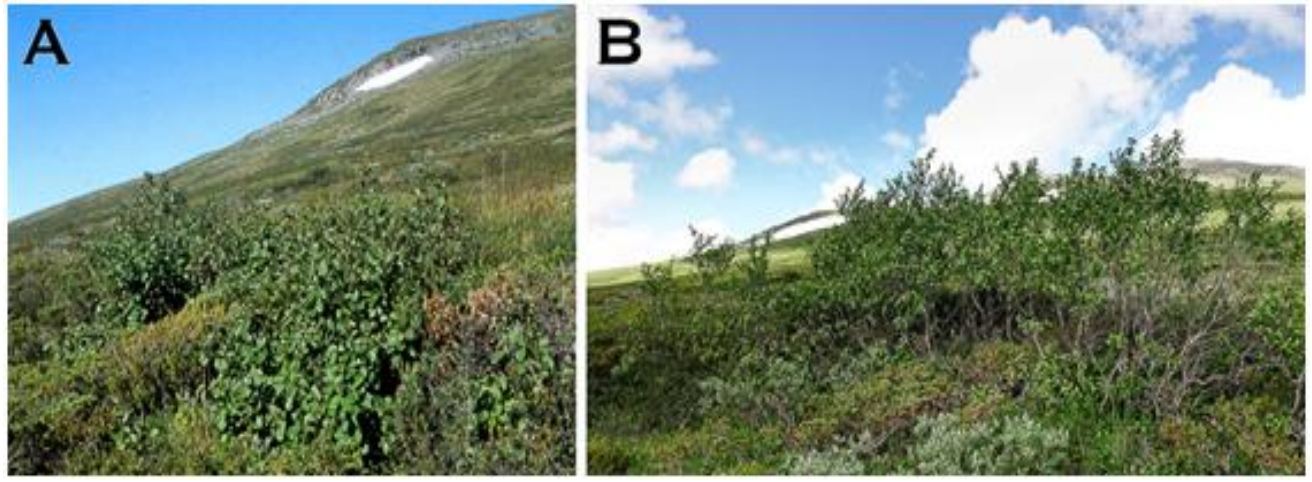

Fig. 34 A. Clonally reproducing multi-stemmed shrub of Alnus incana, maximum $1.2 \mathrm{~m}$ high, $890 \mathrm{~m}$ a.s.l. Photo: 1998-07-22. B. Up to the present day, the entire stand has attained a height of about $3 \mathrm{~m}$. Photo: 2017-08-03.

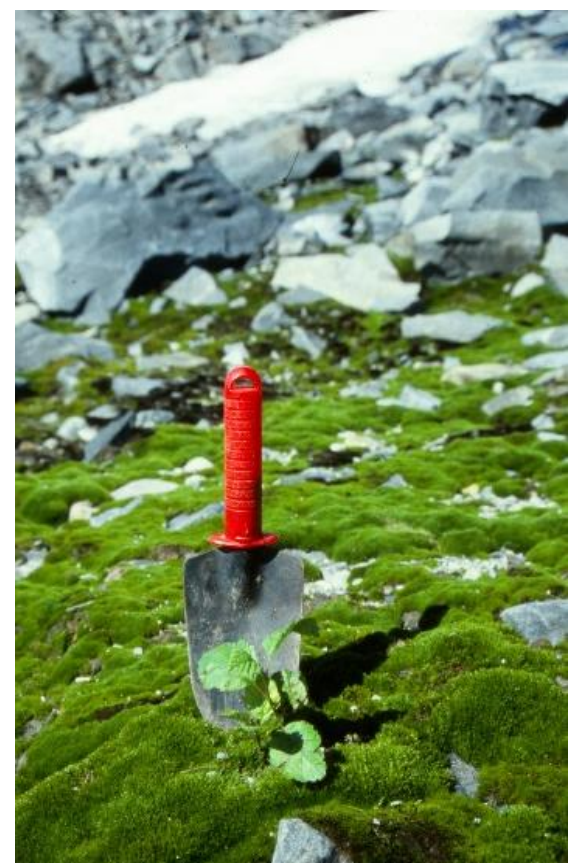

Fig. 35 Young sapling of Alnus incana which has germinated in a moss mat at the fringe of areceeding snow patch, 1060 m a.s.l. Photo: 2004-08-02.

\subsection{Site3. South-West Facing Slope of Mt. Getryggen}

\subsubsection{Birch Treeline}

This slope is exposed to strong westerly winds, which cause a poor snow and a sparse tree cover. Just a few birches prevail in the lower slope. Smith (1920) did not record any birch treeline at all, although (Kilander 1955), mentions from 1949 a $0.2 \mathrm{~m}$ tall shrub, heavily injured by frost $920 \mathrm{~m}$ a.s.l. Today, the treeline is at $945 \mathrm{~m}$ a.s.l. and is formed by widely scattered youngish trees (Fig. 36). A few living older trees exist at $840 \mathrm{~m}$ a.s.l. which reasonably mark the treeline by the early-20th century (Fig. 37). This implies treeline rise by $105 \mathrm{~m}$ during the past 100 years. Megafossil studies show that birch trees grew quite frequently here between 9600 to 3600 cal. yr BP (Kullman 1994) (Fig. 38). 
A One Hundred -Year Study of the Upper Limit of Tree Growth (Terminus Arboreus) in the Swedish Scandes- Updated and Illustrated Change in an Historical Perspective

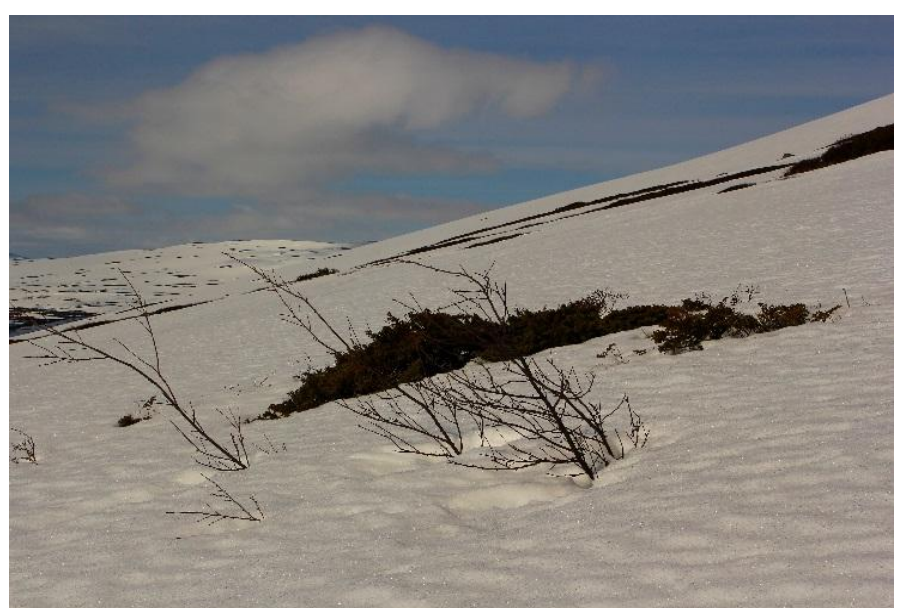

Fig. 36 Raised treeline by 105 m, manifested by conspicuously young birch trees, 945 m a.s.l. Photo: 2011-0430.

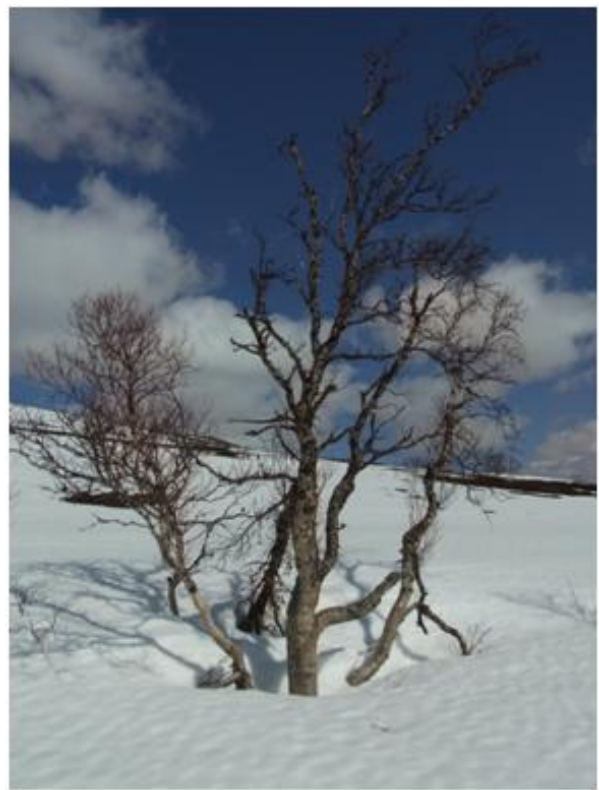

Fig. 37 The treeline position around 1915 is marked by this old-established tree, $840 \mathrm{~m}$ a.s.l. Photo: 2011-0430 .

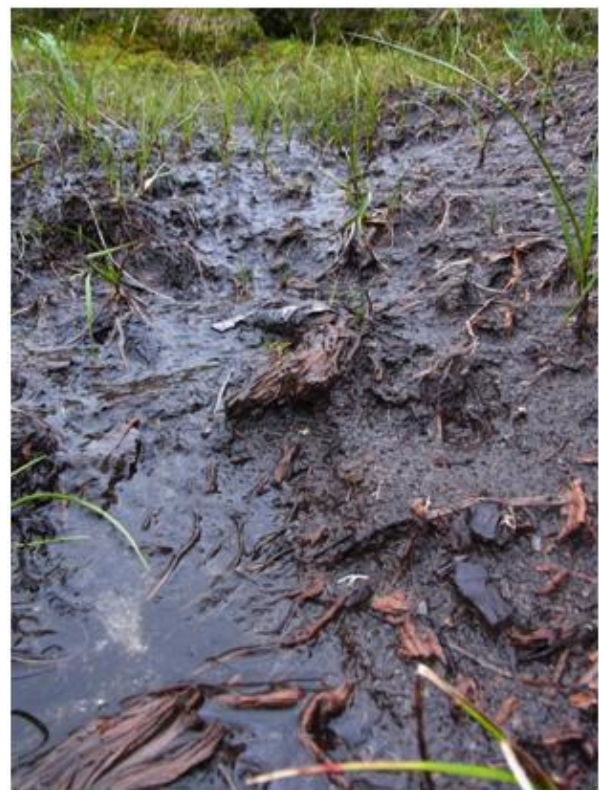

Fig. 38 Megafossil wood debris of birch, exposed in an eroding fen,1000 $\mathrm{m}$ a.s.l. Radiocarbon dating yielded 9600 cal. yr BP. Source: Kullman (1994). 


\subsubsection{Spruce Treeline}

As depicted above, still existing clonal krummholz-mats of Picea abies have prevailed here (about $1000 \mathrm{~m}$ a.s.l.) since at least $6860 \mathrm{cal}$. yr BP (Fig. 7). In a few cases they have produced leaders $(>2 \mathrm{~m}$ tall) in recent years (Fig. 39). Thus, by definition, one may discern the emergence of a current spruce treeline, $1000 \mathrm{~m}$ a.s.l. in this slope, which is about $160 \mathrm{~m}$ above the valley floor. The latter figure may be tentatively used as a minimum reference with the recent treeline position, thereby suggesting secular treeline rise by $160 \mathrm{~m}$. Except for this ancient individual, no other spruces exist on this slope. This specimen further attests to the general pattern of early-Holocene presence of Picea abies in the Swedish Scandes (Kullman 2001, 2008).

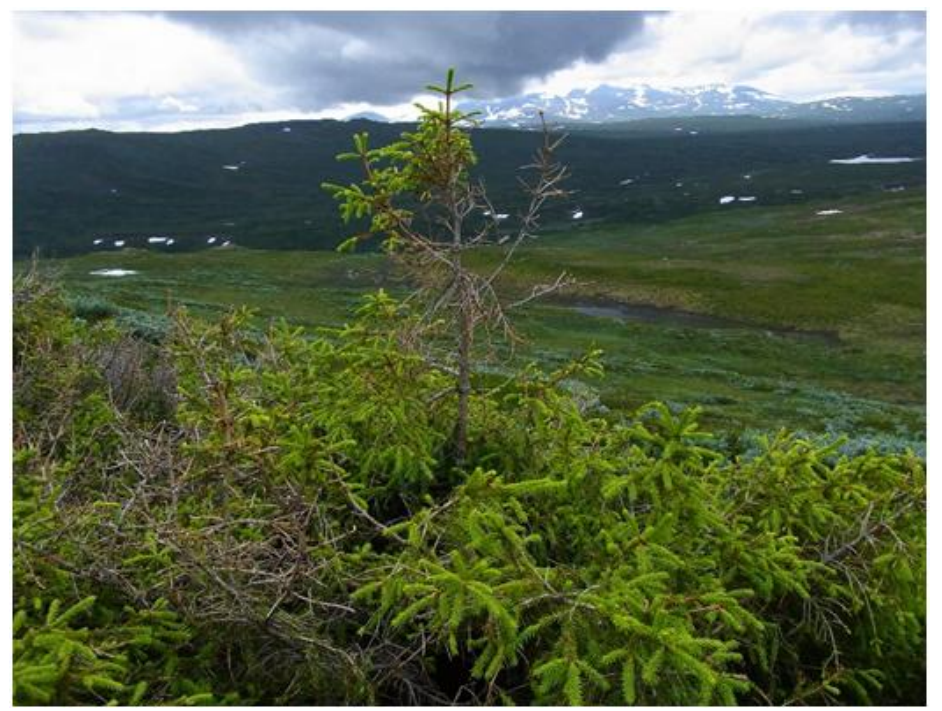

Fig. 39 This ancient krummholz spruce, $1000 \mathrm{~m}$ a.s.l. (see Fig. 7), has produced some leaders 2-2.3 $\mathrm{m}$ tall during the past few years. Thereby, they announce treeline rise, where no tree-sized spruces existed during the past 100 years. Photo: 2012-07-31.

\section{SumMary OF RECENT TREELINE UPSHIFTS}

A summary of treeline advances for all three studied transects is given in Table 1.

Table1. Total treeline upshifts (m) 1915-2017 at the tree investigated transects on Mt. Getryggen (SITE 1-3).

\begin{tabular}{|c|c|c|c|}
\hline Species/Site & SITE 1 & SITE 2 & SITE 3 \\
\hline Betula & 135 & 215 & 105 \\
\hline Picea & 100 & 45 & 160 \\
\hline Pinus & 75 & 10 & no value \\
\hline Alnus & no value & 135 & no value \\
\hline
\end{tabular}

\section{EXPERIMENTAL STUDIES}

Annual birch seed germinability has been assessed since 1972 and up to the present day (Fig.40). Germination occurred all years, with a peak (c. 60\%) for some years around 2002, followed by a downturn tomore modest conditions during subsequent years (20-40\%).

The sowing experiment in contrasting subalpine habitats yielded initially quite high germination rates, although mortality increased rapidly and by the mid-1980s the initial cohort was virtually depleted in all three habitats. After 2001 all seedlings had died. Virtually the same course of change was recorded for the cohort of transplanted saplings. In that case the last few survivors persisted in 2004.

The seed bank experiment yielded steadily lower germination percentages with annual tests. Still after 11 years germinability yielded 4\% (Kullman 1993), but after 1999 no viability has been recorded.

The experimental trial with exotic tree species has been successful with respect to survival and growth. Tested species have survived to the present day with 75-100\%, which contrasts with the control cohort of native Pinus sylvestris, which was entirely extirpated (frost drought) by 2003. With 
respect to growth, Picea engelmannii and Larix sibirica have been most successful and have attained maximum heights of 3.5 and $5 \mathrm{~m}$, respectively (Fig. 41).

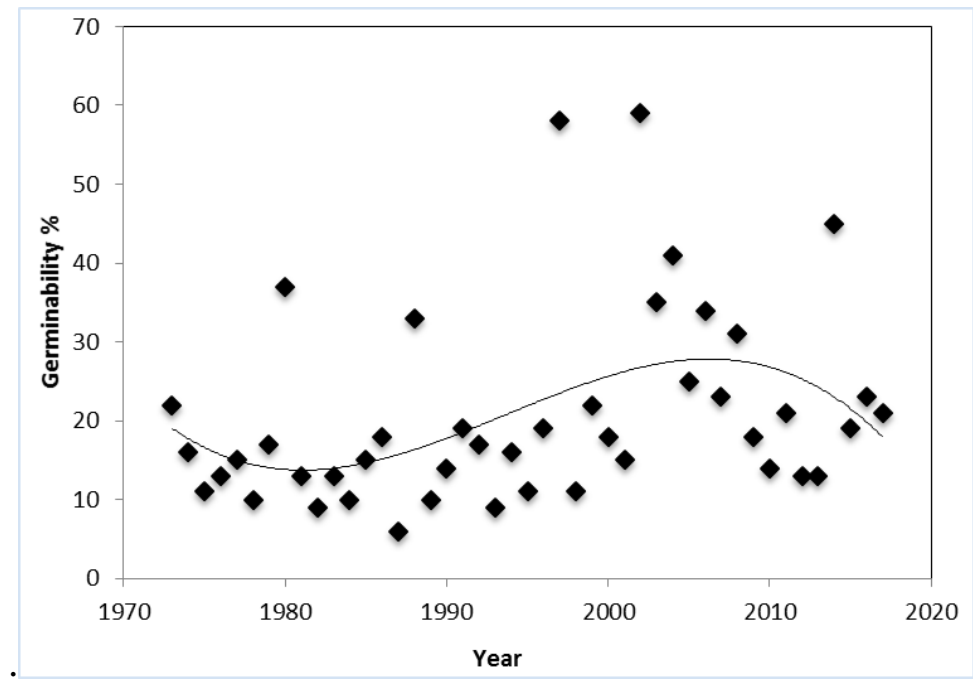

Fig. 40 Annual tests of birch seed viability from trees on the south-facing slope of Mt. Getryggen,775 $m$ a.s.l.
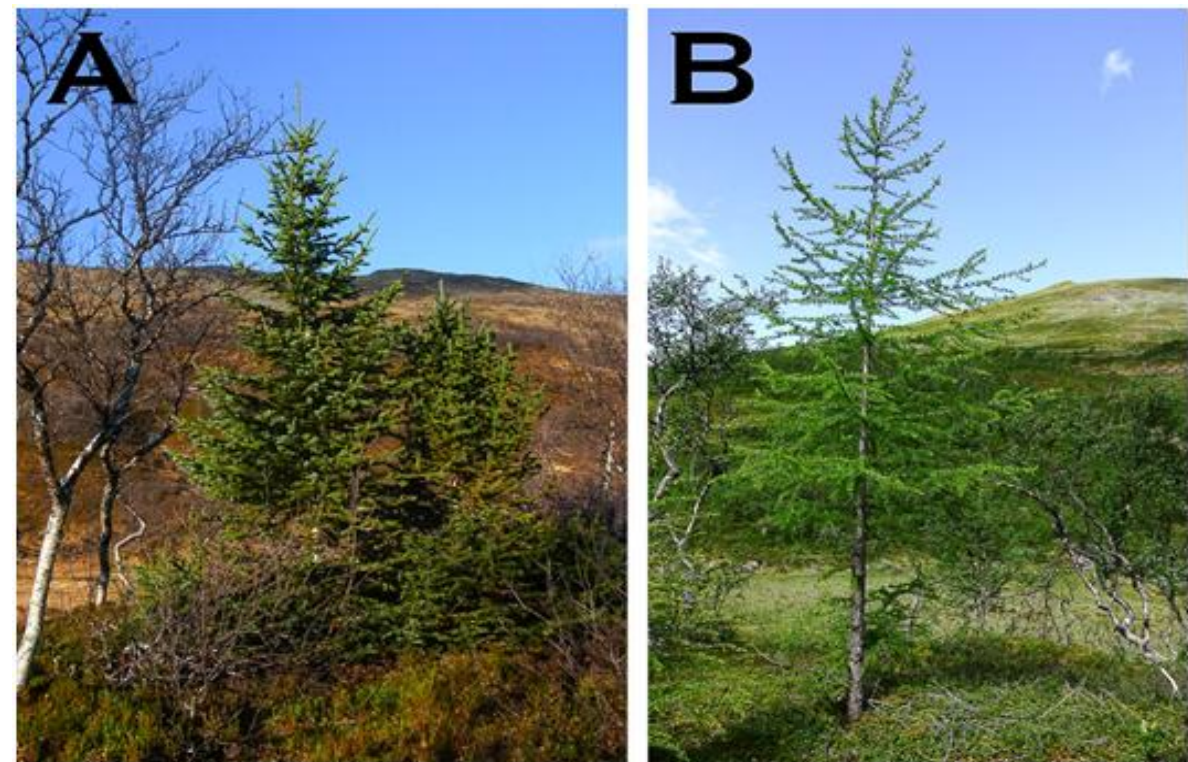

Fig. 41 A. Picea engelmannii is one of the most successful exotic species tested in the mountain birch forest. Photo: 2014-10-16. B. Also Larix sibirica has developed well during the past few decades. Photo: 2016-07-03-

\section{DISCUSSION}

Substantial treeline rise over the past 100 years, relating to the climate warming after the Little Ice Age, characterizes birch and spruce on all three aspects of the study mountain. Treeline stands of these species display a conspicuous lack of dead individuals, which is compatible with quite recent stand rejuvenation and sustained favorable growth conditions for trees and subalpine/alpine vegetation (Kullman 2010; Sundqvist et al. 2008).

Pine has advanced on SITE 1 and 2, while grey alder shifted upslope on SITE 2 only. For all species, the extent of upshift varied substantially between the sites (Table 1). This is an experience also from prior more extensive studies concerning all species focused in this study (Kullman \& Öberg 2009). The reason was found to be local topoclimatic conditions, enabling treeline responses to manifest in subdued form in most parts of the landscape. Although the largest current upshifts display the most clear-cut relationship with climate change, they appear quite infrequently in the treeline landscape. Spatially idiosyncratic responses could imply that even in a hypothetical case of dramatic future climate warming, large expanses of the alpine landscape may remain untreed, as inferred for the warmest part of the Holocene. i.e. 10 500-9000 cal. yr BP (Öberg \& Kullman 2011; Kullman 2013). 
This implies that modelling results, purporting extensive and pending forest encroachment on the alpine tundra (e.g. Kellomäki et al. 1997; Moen et al. 2004) are not validated by recent observations (cf. Holtmeier 2005; Hofgaard et al. 2013). At odds with results from other regionally extensive monitoring studies in the Swedish Scandes over the period 2003-2012 (Hedenås et al. 2016), treeline progression in the concerned area has continued over this period of time. This discrepancy may relate to treeline definition incongruencies with different sensitivities to climate change.

In contrast to birch, treeline rises of other species are manifested by a relatively low densities of new trees atop of the treeline prevailing by the early 20th century. This is particularly valid for pine, which is the species with the lowest treeline, commonly encased in the dense birch forest filter, which restricts its potential to spread (Kullman 2016b). In contrast to extensive treeline rises, a common pattern for all studied species is that forest encroachment on the alpine tundra is patchy and largely negligible. Recent surges of tree species saplings into exceptionally high positions (Kullman 2004, $2007 \mathrm{a}, \mathrm{b})$ appears to be a transient phenomenon as mortality in these cohorts has been substantial during the past few decades (Kullman 2014).

The most extensive treeline advance was displayed at SITE 1 by birch; $215 \mathrm{~m}$. This implies a rate of $21.5 \mathrm{~m}$ per decade, which is double the rate as an average for different taxonomic groups worldwide (Chen et al. 2011; Aakala et al. 2014).Recent treeline advance with this magnitude is an interregionally recurrent pattern along the Swedish Scandes. Analogously high values have been obtained for birch and other tree species in different regions from south to north along six degrees latitude (Kullman \& Öberg 2009; Öberg \& Kullman 2012; Kullman 2015a,b, 2016a,b, 2018). This geographically common response pattern, at odds with other studies (e.g. Dalen \& Hofgaard 2005), indicates that climate change during the past 100 years is the ultimate driver of treeline change. This contention is further strengthened by the fact that treeline rise by more than $200 \mathrm{~m}$ corresponds quite well with recorded secular warming (1915-2017) by $1.5^{\circ} \mathrm{C}$ and a temperature lapse rate of $0.6{ }^{\circ} \mathrm{C}$ per $100 \mathrm{~m}$ altitude (Laaksonen 1976). Moreover, the present results provide little support (cf. Kullman 2015b) of generalizations that treeline birch population dynamics is primarily driven by reindeer grazing, as purported by Van Bogaert et al. (2011).

The recent course of treeline upshifts represents a fundamental reversal in the long-term descending treeline and climate trend (Kullman 2003), which appears quite unexpected in terms of known natural forcings. Birch treeline rise by maximum $215 \mathrm{~m}$ implies, in perspective of the regional Holocene birch treeline history (Kullman 2013), that recent advance has reached an elevation unprecedented during the past 5600 years. With respect to Pinus in the southern Swedish Scandes, the corresponding figure is about 7000 years ago (Kullman 2016a). In view of the current discourse concerning future climate change, these early dates of equal or higher-than-present treeline, could be interpreted in terms that current temperatures are unprecedented during the past 6000-7000 years. This contention is compatible with glacier histories from widely different parts of the world (e.g. Koch et al. 2014). However, with respect to Scandinavian treelines, such an interpretation may be premature sincethe new trees above the old treeline are quite few and generally of small stature, as shown in this study.This implies that they may not leave any discernible imprint on the fossil record. Accordingly, similar episodes may have happened unrecorded in the past, which would make the recent upshift less unusual in an historical perspective. For example substantial local treeline upshifts have been recorded elsewhere in the southern Swedish Scandes about 2000 and 1000 year before today (Kullman 2013, 2015b).

As evident from SITE 2, birch treeline rise after 2007, appears to have been accomplished to some extent by rapid height growth of seed-regenerated monocormic birches. This contrasts with predominant phenotypic responses of old-growth polycormic krummholz specimens responsible for treeline shift prior to 2007 (cf. Kullman 2010; Öberg \& Kullman 2012). Whether this new phenomenon bears any significant relation to recorded seed viability increase during the past 20 years is uncertain, since, according to ring counts, at least some specimens in the advance zone are older than peak germination around AD 2000. In addition, experimental studies, accounted for above, have evidenced poor establishment and survival rates of seedlings and small saplings during recent decades. Treeline rise has occurred contemporaneously with declining conditions for early growth and 
survival of experimental specimens. Thus climatic constraints to those early life stages do not seem to have improved in recent years and may not restrict and advance. A critical growth phase, with respect to birch treeline performance, appears to relate to the average depth of the snow cover and the height of the warm boundary layer, when plants enter the early mature phase (cf. Körner 1998; Grace et al. 2002). Plants higher than that have good chances to survive and reach maturity, as evident by the progression of planted exotic tree species. These were clearly higher than the maximum snow depth when planted.

The strong reliance of vegetative regeneration of old-established specimens in connection with recent treeline performance of Betula and Picea, could imply a substantial degree of vegetation stability (Aerts et al. 2006; Auger \& Payette 2010). Further upshifts of these treelines are restricted as the pool of krummholz specimens above the present treeline becomes depleted. Many candidate individuals have already attained tree size (Kullman 1993, 2013; Kullman \& Öberg 2009).

\section{REFERENCES}

[1] Aakala, T., Hari, P., Dengel, S., Newberry, S.L., Mizunuma, T. \& Grace, J. 2014. A prominent stepwise advance of the tree line in north-east Finland. Journal of Ecology 102, 1582-1591.

[2] Aas, B. 1969. Climatically raised birch lines in southeastern Norway. Norsk Geografisk Tidsskrift 23, 119-130.

[3] ACIA 2005. Arctic Climate Impact Assessment. Cambridge University Press, Cambridge.

[4] Aerts, R., Cornelissen, J.H.C. \& Dorrepal, E. 2006. Plant performance in a warmer world: general responses of plants from cold, northern biomes and the importance of winter and spring events. Plant Ecology 182, 65-77.

[5] Alexandersson, H. 2006. Klimat i förändring. En jämförelse av temperatur och nederbörd 1991-2005 med 1961-1990. SMHI Faktablad 29, 1-8.

[6] Bergman, J., Hammarlund, D., Hannon, G., Barnekow, L. \& Wohlfarth, B. 2005. Deglacial vegetation succession and Holocene tree-limit dynamics in the Scandes Mountains, west-central Sweden: stratigraphic data compared to megafossil evidence. Review of Palaeobotany and Palynology 134, 129-151.

[7] Burt, T.P. 1994. Long-term study of the natural environment - perspective science or mindless monitoring. Physical Geography 18, 475-496.

[8] Chen, I.-C., Hill, J.K., Ohlemüller, R. Roy, D.B., Thomas, C.D. 2011. Rapid range shift of species associated with high levels of climate warming. Science 333, 1024-1026.

[9] Dalen, L. \& Hofgaard, A. 2005. Differential regional treeline dynamics in the Scandes Mountains. Arctic, Antarctic, and Alpine Research 37, 284-296.

[10] Danby, R.K. \& Hik, D.K. 2007. Variability, contingency and rapid change in recent subarctic alpine treeline dynamics. Journal of Ecology 95, 352-363.

[11] Elliott, G.P. 2011. Influences of 20th-century warming at the upper tree line contingent on local-scale interactions: evidence froma latitudinal gradient in the Rocky Mountains, USA. Global Ecology and Biogeography 20, 46-57.

[12] Elliott, G.P. \& Kipfmueller, 2010. Multi-scale influences of slope aspect and spatial pattern on ecotonal dynamics at upper treeline in the Southern Rocky Mountains U.S.A. Arctic, Antarctic, and Alpine Research 42, 45-56.

[13] Elven, R., Fremstad, E. \& Pedersen, O. 2013. Distribution maps of Norwegian vascular plants. IV The eastern and northeastern elements. Akademika Publishing, Trondheim.

[14] Fagre, D.B., Peterson, D.L. \& Hessle, A.E. 2003. Taking the pulse of mountains: ecosystem responses to climatic variability. Climate Change 59, 263-282.

[15] Fuentes, M., Salo, R., Björklund, J. 2017. A 970-year-long summer temperature reconstruction from Rogen, west-central Sweden, based on blue intensity from tree rings. The Holocene 28, 254-266.

[16] Gaire, N.P., Koirala, M., Bhuju, D.R. \& Borgaonkar, H.P. 2014. Treeline dynamics with climate change at the central Nepal Himalaya. Climate of the Past 10, 1277-1290.

[17] Giesecke T. 2005. Holocene forest development in the central Scandes Mountains, Sweden. Vegetation History and Archaeobotany 14, 133-147.

[18] Grace, J., Berninger, F. \& Nagy, L. 2002. Impacts of climate change on the treeline. Annals of Botany 90, 537-544.

[19] Grove, J.M. 1988. The Little Ice Age. Methuen, London. 
A One Hundred -Year Study of the Upper Limit of Tree Growth (Terminus Arboreus) in the Swedish Scandes- Updated and Illustrated Change in an Historical Perspective

[20] Hafsten, U. 1992. The immigration and spread of Norway spruce (Picea abies (L.) Karst) in Norway. Norsk Geografisk Tidsskrift 46, 121-158

[21] Harsch, M.A., Hulme, P.E., McGlone, M.S. \& Duncan, R.P. 2009. Are treelines advancing? A global meta-analysis of treeline response to climate warming. Ecology Letters 12, 1040-1049.

[22] Harsch, M.A. \& Bader, M.Y. 2011. Treeline form - a potential key to understanding treeline dynamics. Global Ecology and Biogeography 20, 582-596.

[23] Hedenås, H., Christensen, P.\& Svensson, J. 2016. Changes in vegetation cover and composition in the Swedish mountain region. Environmental Monitoring and Assessment 188, 1-15.

[24] Hiller, A., Boettger, T. \& Kremenetski, C. 2001. Mediaeval climate warming recorded by radiocarbon dated alpine treeline shift on the Kola Peninsula. The Holocene 11, 491-497.

[25] Hofgaard, A., Tømmervik, H., Rees, G. \& Hanssen, F. 2013. Latitudinal forest advance in northernmost Norway since the early 20th century. Journal of Biogeography 40, 938-949.

[26] Holtmeier, F.-K. 2003. Mountain timberlines: ecology, patchiness, and dynamics. Springer, Dordrecht.

[27] Holtmeier, F.-K. \& Broll, G. 2005. Sensitivity and response of northern hemisphere altitudinal and polar treelines to environmental change at landscape and local scales. Global Ecology and Biogeography 14, 395-410.

[28] Holtmeier, F.-K. \& Broll, G. 2011. Response of Scots pine (Pinus sylvestris) at its altitudinal limit in northernmost subarctic Finland to warming climate. Arctic 64, 269-280.

[29] Huntley, B. \& Birks, H.J.B. 1983. An atlas of past and present pollen maps for Europe 0-13 000 years ago. Cambridge University Press, Cambridge.

[30] Hustich, I. 1979. Ecological concepts and biogeographical zonation in the north: the need for a generally accepted terminology. Holarctic Ecology 2, 208-217.

[31] IPCC 2013. Climate change 2013. Cambridge University Press, Cambridge and New York.

[32] Kaplan, J.O. \& New, M. 2006. Arctic climate change with a $2{ }^{\circ} \mathrm{C}$ global warming: Timing, climate patterns and vegetation change. Climatic Change 79, 213-241.

[33] Kapralov, D.S., Shiyatov, S.G., Moiseev, P.A. \& Fomin, V.V. 2006. Changes in composition, structure, and altitudinal distribution of low forests at the upper limit of their growth in the Northern Ural Mountains. Russian Journal of Ecology, 37, 367-372.

[34] Kellomäki, S., Väisänen, H. \& Kolström, T. 1997. Model computations on the effect of elevated temperature and atmospheric $\mathrm{CO}_{2}$ on the regeneration of Scots pine at the timberline in Finland. Climatic Change 37, 683-708.

[35] Kilander, S. 1955. Kärlväxternas övre gränser på fjäll i sydvästra Jämtland samt angränsande delar av Härjedalen och Norge. Acta Phytogeographica Suecica 35, 1-198.

[36] Koch, J., Clague, J.J. \& Osborn, G. 2014. Alpine glaciers and permanent ice and snow patches in western Canada approach their smallest sizes since the mid-Holocene, consistent with global trends. The Holocene 24, 1639-1648.

[37] Körner, C. 1998. A re-assessment of high elevation treeline positions and their explanation. Oecologia 115, 445-459.

[38] Körner, C. \& Paulsen, J. 2004. A world-wide study of high-altitude treeline temperatures. Journal of Biogeography.31, 713-732.

[39] Kullman, L. 1979. Change and stability in the altitude of the birch tree-limit in the southern Swedish Scandes. Acta Phytogeographica Suecica 65, 1-121.

[40] Kullman, L. 1984. Transplantation experiments with saplings of Betula pubescens ssp. tortuosa near the tree-limit in Central Sweden. Holarctic Ecology 7, 289-293.

[41] Kullman, L. 1985. Växtbiografi - ett komplement i föryngringsforskningen. Sveriges Skogsvårdsförbunds Tidskrift 80, 3-9.

[42] Kullman, L. 1986a. Demography of Betula pubescens ssp. tortuosa sown in contrasting habitats close to the birch tree-limit in Central Sweden. Vegetatio 65, 13-20.

[43] Kullman, L. 1986b. Recent treeline history of Picea abies in the southern Swedish Scandes. Canadian Journal of Forest Research 16, 761-771.

[44] Kullman, L. 1989. Cold-induced dieback of montane spruce forest in the Swedish Scandes - a modern analogue of palaeoenvironmental processes. New Phytologist 113, 377-381.

[45] Kullman, L. 1992. The ecological status of grey alder (Alnus incana (L.) Moench) in the upper subalpine birch forest of the central Scandes. New Phytologist 120, 445-451. 
[46] Kullman, L. 1993. Tree limit dynamics of Betula pubescens ssp. tortuosa in relation to climate variability: evidence from central Sweden. Journal of Vegetation Science 4, 765-772.

[47] Kullman, L. 1994. The Holocene history of a subalpine birch forest enclave: subfossil evidence from central Sweden. Géographie physique et Quaternaire 48, 151-156.

[48] Kullman, L. 1996. Norway spruce present in the Scandes Mountains, Sweden at 8000 BP: new light on Holocene tree spread. Global Ecology and Biogeography 5, 94-101.

[49] Kullman, L. 1998a. Tree limits and montane forests in the Swedish Scandes: sensitive biomonitors of climate change and variability. Ambio 27, 312-321.

[50] Kullman, L. 1998b. Non-analogous tree flora in the Scandes Mountains, Sweden, during the early Holocene macrofossil evidence of rapid geographic spraed and response to palaeoclimate. Boreas 27, 153-161.

[51] Kullman, L. 1998c. The occurrence of thermophilous trees in the Scandes Mountains during the early Holocene: evidence for a diverse tree flora from macroscopic remains. Journal of Ecology 89, 421-428.

[52] Kullman, L. 2001. Immigration of Picea abies into North - Central Sweden. New evidence of regional expansion and tree-limit evolution. Nordic Journal of Botany 21, 39-54.

[53] Kullman, L. 2002. Boreal tree taxa in the central Scandes during the Late-Glacial: implications for LateQuaternary forest history. Journal of Biogeography 29, 1117-1124.

[54] Kullman, L. 2003. Recent reversal of Neoglacial climate cooling trend in the Swedish Scandes as evidenced by mountain birch tree-limit rise. Global and Planetary Change 36, 77-88.

[55] Kullman, L. 2004. A face of global warming - "Ice birches" and a changing alpine plant cover. Geo-Öko $25,181-202$.

[56] Kullman, L. 2007a. Long-term geobotanical observations of climate change impacts in the Scandes of West-Central Sweden. Nordic Journal of Botany 24, 445-467.

[57] Kullman, L. 2007b. Modern climate change and shifting ecological states of the subalpine/alpine landscape in the Swedish Scandes. Geo-Öko 28, 187-221.

[58] Kullman, L. 2008. Early postglacial appearance of tree species in northern Scandinavia: review and perspective. Quaternary Science Reviews 27, 2467-2472.

[59] Kullman, L. 2010. A century of treeline change and stability-experiences from the Swedish Scandes. Landscape Online 17, 1-31.

[60] Kullman, L. 2012.The alpine treeline ecotone in the southernmost Swedish Scandes: dynamism on different scales. In: Myster R.W. (ed), Ecotones between forest and grassland. Springer, New York.

[61] Kullman, L. 2013. Ecological tree line history and palaeoclimate - review of megafossil evidence from the Swedish Scandes. Boreas 42, 555-567.

[62] Kullman, L. 2014. Recent cooling and dynamic responses of alpine summit floras in the southern Swedish Scandes. Nordic Journal of Botany 32, 369-376.

[63] Kullman, L. 2015a. Trädgräns i fjällen. Sammanställning och utvärdering av en metodstudie för klimatrelaterad miljöövervakning. Länsstyrelsen i Jämtlands län (www.lansstyrelsen.se/jamtland).

[64] Kullman, L. 2015b. Recent and past trees at the Arctic/Alpine margin in Swedish Lapland: an Abisko case study review. Journal of Biodiversity Management \& Forestry 15, 4:4.

[65] Kullman, L. 2015c. Higher-than-present Medieval pine (Pinus sylvestris) treeline along the Swedish Scandes. Landscape Online 42, 1-14.

[66] Kullman, L. 2016a. Fjällen, klimatet och människan - naturhistoria mellan två istider. Svensk Botanisk Tidskrift 110, 132 - 272. In Swedish with a summary in English.

[67] Kullman, L. 2016b.Pine (Pinus sylvestris L.) penetration towards the head of the Handölan Valley: recent reversal of long-term retrogressional trend -contrasting responses to climate change of tree- and forest line. International Journal of Environmental \& Agriculture Research 2(5), 163-172.

[68] Kullman, L. 2016c. Climate change and primary birch forest (Betula pubescens ssp. czerepanovii) succession in the treeline ecotone of the Swedish Scandes. International Journal of Research in Geography 2(2), 36-47.

[69] Kullman, L. 2017a. Pine (Pinus sylvestris) performance in the southern Swedish Scandes since the early 20th century. Acta Phytogeographica Suecica 90, 1-46.

[70] Kullman, L. 2017b. Melting glaciers in the Swedish Scandes provide new insights into palaeotreeline performance. International Journal of Current Multidisciplinary Studies 3, 607-618.

[71] Kullman, L. 2018. Recent treeline shift in the Kebnekaise Mountains, northern Sweden - a climate change case. International Journal of Current Research 10, 63786-63792. 
[72] Kullman, L. \& Kjällgren, L. 2006. Holocene pine tree-line evolution in the Swedish Scandes: recent treeline rise and climate change in a long-term perspective. Boreas 35, 159-168.

[73] Kullman, L. \& Öberg, L. 2009. Post-Little Ice Age rise and climate warming in the Swedish Scandes: a landscape ecological perspective. Journal of Ecology 97, 415-429.

[74] Laaksonen, K. 1976. The dependence of mean air temperature upon latitude and altitude in Fennoscandia. Annales Academiae Scientiarum Fennicae. A3, 1-19.

[75] Lamb, H. 2005. Climate, History and the Modern World. Taylor \& Francis, London.

[76] Leonelli, G., Pelfini, M., Morra di Celia, U. \& Garavaglia, V. 2011. Climate warming and the recent treeline shift in the European Alps. The role of geomorphological factors in high-altitude sites. Ambio 40, 264-273.

[77] Leonelli, G., Masseroli, A. \& Pelfini, M. 2016. The influence of topographic variables on treeline trees under different environmental conditions. Physical Geography 37, 56-73.

[78] Lloyd, A.H. 2005. Ecological histories from Alaskan tree lines provide insight into future change. Ecology 86, 1687-1695.

[79] Mamet, S.D. \& Kershaw, G.P. 2012. Subarctic and alpine tree line dynamics during the last 400 years in north-western and central Canada. Journal of Biogeography 39, 855-868.

[80] Miehe, G. \& Miehe S. 2000. Comparative high mountain research on the treeline ecotone under human influence. Erdkunde 54, 34-50.

[81] Moen, J., Aune, K., Edenius, L. \& Angerbjörn, A. 2004. Potential effects of climate change on treeline position in the Swedish Mountains. Ecology \& Society 9, 1-10.

[82] Müller, M., Schickhoff, U., Scholten, T., Drollinger, S., Böhner, J. \& Chaudhary, R.P. 2016. How do soil properties affect alpine treelines? General principles in a global perspective and novel findings from Rolwaling Himal, Nepal. Progress in Physical Geography 40, 135-160.

[83] Nagy, L. 2006. European high mountain (alpine) vegetation and its suitability for indicating climate impacts. Biology and Environment: Proceedings of the Royal Irish Academy 106B, 335-341.

[84] Nagy, J., Nagy, L., Legg, C.J. \& Grace, J. 2013. The stability of Pinus sylvestris tree line in the Cairngorms, Scotland over the last millennium. Plant Ecology \& Diversity 6, 7-19.

[85] Öberg, L. \& Kullman, L. 2011. Recent glacier recession - new source of postglacial treeline and climate history in the Swedish Scandes. Landscape Online 26, 1-38.

[86] Öberg, L. \& Kullman, L. 2012. Contrasting short-term performance of mountain birch (Betula pubescens ssp. czerepanovii) treeline along a latitudinal continentality-maritimity gradient in the southern Swedish Scandes. Fennia 190, 19-40.

[87] Olofsson, J., Oksanen, L., Callaghan, T., Hulme, P.E., Oksanen, T. \& Suominen, O. 2009. Herbivores inhibit climate driven shrub expansion on the tundra. Global Change Biology 15, 2681-2693.

[88] Raab, B. \& Vedin, H. 1995. Climate, lakes and rivers. In: National Atlas of Sweden. Sveriges Nationalatlas Förlag, Stockholm.

[89] Rannow, S. 2013. Do shifting forest limits in south-west Norway keep up with climate change? Scandinavian Journal of Forest Research 28, 574-580.

[90] Schickhoff, U., Bobrowski, M., Böhner, J., Bürzle, B., Chaudhary, R.P., Gerlitz, L., Heyken, H., Lange, J., Müller, M., Scholten, T., Schwab, N. \& Wedegärtner, R. 2015. Do Himalayan treelines respond to recent climate change? An evaluation of sensitivity indicators. Earth System Dynamics 6, 245-265.

[91] Selsing, L. 2010. Mennesker og natur i fjellet i Sør-Norge etter siste istid. Med hovedvekt på mesolitikum. AmS-Varia 51, 1-368.

[92] Shiyatov, S.G. 2003. Rates of change in the upper treeline ecotone in the Polar Ural Mountains.PAGES News 11, 8-10.

[93] Smith, H. 1920. Vegetationen och dess utvecklingshistoria i det centralsvenska högfjällsområdet. Almqvist \& Wicksells, Uppsala.

[94] Smith, H. 1957. En botanisk undersökning av Neans dalgång. Kgl. Sven. Vetensk.-Akad. Avhandl. Naturskyddsärenden 16, 1-21.

[95] Sundqvist, M.K., Björk, R.G. \& Molau, U. 2008. Establishment of boreal forest species in alpine dwarfshrub heath in Subarctic Sweden. Plant Ecology \& Diversity 1, 67-75.

[96] Tranquillini, W. 1979. Physiological ecology of the alpine timberline. Springer-Verlag. Berlin and Heidelberg.

[97] Van Bogaert, R., Haneca, K., Hoogesteger, J., Jonasson, C., De Dapper, M. \& Callaghan, T.V. 2011. A century of tree line changes in sub-Arctic Sweden shows local and regional variability and only minor influence of 20th century climate warming. Journal of Biogeography 38, 907-921. 
A One Hundred -Year Study of the Upper Limit of Tree Growth (Terminus Arboreus) in the Swedish Scandes- Updated and Illustrated Change in an Historical Perspective

[98] Virtanen, R., Eskelinen, A. \& Gaare, E. 2003. Long-term changes in alpine plant communities in Norway and Finland. In: Alpine Biodiversity in Europe (eds. Nagy, L., Grabherr, G., Körner, C. \& Thompson, D.B.A.).Springer, Berlin.

[99] Wistrand, G. 1962. Studier i Pite Lappmarks kärlväxtflora med särskild hänsyn till skogslandet och de isolerade fjällen. Acta Phytogeographica Suecica 45, 1-211.

\section{AUTHOR'S BIOGRAPHY}

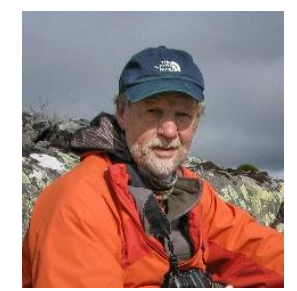

Leif Kullman is professor of Physical Geography and Plant Ecology at Umeå University, Sweden. His research is focused on treeline-climate dynamics at widely different temporal and spatial scales.

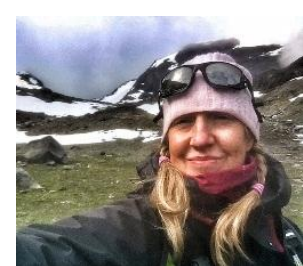

Lisa Öberg has a PhD in biology at the Mid Sweden University, Sundsvall. She has broad interests and skills in subalpine/alpine, plant ecology and physical geography.

Citation:Leif Kullman, Lisa Öberg. "A One Hundred-Year Study of the Upper Limit of Tree Growth (Terminus Arboreus) in the Swedish Scandes- Updated and Illustrated Change in an Historical Perspective”. International Journal of Research in Geography. vol 4, no. 3, 2018, pp. 10-35.doi: http://dx.doi.org/10.20431/ 2454-8685.0403002.

Copyright:@ 2018 Authors. This is an open-access article distributed under the terms of the Creative Commons Attribution License, which permits unrestricted use, distribution, and reproduction in any medium, provided the original author and source are credited. 